\title{
Synthesis, spectroscopic characterization and biological evaluation of unsymmetrical aminosquarylium cyanine dyes
}

\author{
Sofia Friães ${ }^{\mathrm{a}, \mathrm{b}}$, Amélia M. Silva ${ }^{\mathrm{b}, \mathrm{c}, *}$, Renato E. Boto ${ }^{\mathrm{d}}$, Diana Ferreira ${ }^{\mathrm{e}}$, José R. Fernandes ${ }^{\mathrm{f}}$, Eliana B. Souto ${ }^{\mathrm{g}, \mathrm{h}}$, \\ Paulo Almeida ${ }^{\mathrm{d}}$, Luis F. Vieira Ferreira ${ }^{\mathrm{e}}$, Lucinda V. Reis ${ }^{\mathrm{a}, *}$ \\ a Department of Chemistry and CQ-VR, UTAD, Quinta de Prados, 5001-801 Vila Real, Portugal \\ ${ }^{\mathrm{b}}$ Centre for Research and Technology of Agro-Environmental and Biological Sciences, CITAB, UTAD, Quinta de Prados, 5001-801 Vila Real, Portugal \\ ${ }^{\mathrm{C}}$ Department of Biology and Environment, University of Trás-os-Montes e Alto Douro, UTAD, Quinta de Prados, 5001-801 Vila Real, Portugal \\ ${ }^{\mathrm{d}}$ CICS-UBI - Health Sciences Research Centre, University of Beira Interior, Av. Infante D. Henrique, 6201-506 Covilhã, Portugal \\ ${ }^{e}$ CQFM-Centro de Química-Física Molecular and IN-Institute of Nanoscience and Nanotechnology, Instituto Superior Técnico, Universidade Técnica de Lisboa, Av. Rovisco Pais, \\ 1049-001 Lisboa, Portugal \\ f INESC-TEC Porto and Department of Physics, University of Trás-os-Montes e Alto Douro, UTAD, Quinta de Prados, 5000-801 Vila Real, Portugal

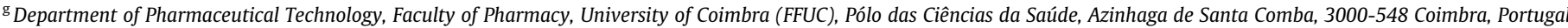 \\ ${ }^{\mathrm{h}}$ REQUIMTE/LAQV, Group of Pharmaceutical Technology, Faculty of Pharmacy, University of Coimbra, 3000-548 Coimbra, Portugal
}

\section{A R T I C L E I N F O}

\section{Article history:}

Received 20 February 2017

Revised 7 May 2017

Accepted 10 May 2017

Available online 11 May 2017

\section{Keywords:}

Unsymmetrical aminosquarylium cyanine

dyes

Singlet oxygen

Caco-2 cells

HepG2 cells

Cell viability

Photosensitizers

\begin{abstract}
A B S T R A C T
New unsymmetrical aminosquarylium cyanine dyes were synthesized and their potential as photosensitizers evaluated. New dyes, derived from benzothiazole and quinoline, were prepared by nucleophilic substitution of the corresponding $O$-methylated, the key intermediate that was obtained by methylation with $\mathrm{CF}_{3} \mathrm{SO}_{3} \mathrm{CH}_{3}$ of the related zwitterionic unsymmetrical dye, with ammonia and methylamine, respectively. All three news dyes herein described displayed intense and narrow bands in the Vis/NIR region (693-714 nm) and their singlet oxygen formation quantum yields ranged from 0.03 to 0.05 . In vitro toxicity, in Caco-2 and HepG2 cells, indicated that dark toxicity was absent for concentrations up to $5 \mu \mathrm{M}$ (for the less active dye) or up to $1 \mu \mathrm{M}$ (for the two more active dyes). The three dyes present potential as photosensitizers, differing in irradiation conditions and period of incubation in the presence of irradiated dye. The less active dye needs a longer irradiation period to exhibit phototoxicity which is only evident after longer period of contact with cells $(24 \mathrm{~h})$. However, the remaining two more active dyes produce higher phototoxicity, even at shorter incubation periods $(1 \mathrm{~h})$, with shorter irradiation time $(7 \mathrm{~min})$. Although in different extents, these dyes show promising in vitro results as photosensitizers.
\end{abstract}

(c) 2017 Elsevier Ltd. All rights reserved.

\section{Introduction}

Squaraine dyes, also called squaraines, can be regarded as derivatives of cyanine dyes as they result from the introduction of a squaraine ring in the cyanine polymethine chain. ${ }^{1}$ These dyes resulting from the condensation of one molar equivalent of squaric acid with two molar equivalents of aromatic or heterocyclic methylene bases, ${ }^{2}$ exhibit special properties such as high photoconductivity, good photochemical stability, sharp and intense

\footnotetext{
* Corresponding authors at: Department of Biology and Environment, School of Life and Environmental Sciences, University of Trás-os-Montes e Alto Douro (UTAD), Quinta de Prados, 5001-801 Vila Real, Portugal (A.M. Silva). Department of Chemistry and CQ-VR, School of Life and Environmental Sciences, University of Trás-os-Montes e Alto Douro (UTAD), Quinta de Prados, 5001-801 Vila Real, Portugal (L.V. Reis).

E-mail addresses: amsilva@utad.pt (A.M. Silva), lucinda.reis@utad.pt (L.V. Reis).
}

absorption in the visible and near infrared regions, high quantum yield and high molar absorption coefficient. ${ }^{3-6}$ These properties make squaraine dyes very attractive for several photonic applications, such as optical recording media, organic solar cells and xerographic photoreceptors, ${ }^{7,8}$ as well as for biological and biomedical applications, such as fluorescent markers and labels ${ }^{9}$ and sensitizers for photodynamic therapy (PDT), also known as photosentizers. $^{5}$

PDT is a promising treatment modality for several type of diseases, such as cancer, which requires the delivery of a photosensitising drug into the target tissue and/or cells, followed by exposure of the target region with light of appropriate wavelengths which gives rise to a cascade of photochemical and biochemical processes leading to destruction of the abnormal cells. ${ }^{10}$ The use of PDT in cancer therapy is particularly interesting, mainly for skin cancer, because the photosensitizer (PS) can selectivity be applied through the malignant tissue. The light, used to activate the PS to induce 
the generation of reactive oxygen species (ROS), is then directly focused on the lesion, enabling the destruction of tumour tissue while preserving the healthy one. ${ }^{11,12}$ Also, new technologies that ensure the targeted delivery of PS to the tumour tissue, followed by appropriate irradiation, seem to ensure enhanced selectivity and induce less side effects to the patients. ${ }^{12,13}$ The effectiveness of PDT depends however on several factors, such as the PS location, irradiation conditions and tissue oxygenation. ${ }^{14}$ These factors, altogether, determine the mechanism of cell death that will be induced, i.e. apoptosis, necrosis or autophagy. ${ }^{14-16}$ However, it is commonly accepted that singlet oxygen is the main cytotoxic species responsible for the biological effects developed during PDT treatment resulting mainly in apoptosis.,17 Another important feature of PDT is that the light sources used for irradiation are non-ionizing which also reduces toxicity to tissues that did not incorporate the PS. ${ }^{12}$

The light source should present spectral characteristics that overlap with the maximum absorption wavelength of the used PS, in order to activate the PS and generate enough ROS to produce a cytotoxic effect. ${ }^{18}$ For irradiation in PDT, lasers (pulsed or continuous) and incoherent light, such as intense pulsed light (IPL) or light-emitting diode (LED), have been used. ${ }^{19}$ LED light sources have become increasingly popular, also for application in PDT, since they have a low cost, can be displayed in arrays that allow the irradiation of large areas and can emit a narrow spectrum of light that matches the absorption spectra of the PS used. ${ }^{20}$ On the other hand, LEDs emit light with low-intensity without generating heat, thus no cooling system is required, and irradiation does not cause pain or other discomfort. It has been therefore accepted that this irradiation system consists in a simple alternative to more complicated and expensive PDT units. ${ }^{21}$

Ideally, PS for PDT should meet several characteristics, amongst which an inherent ability to produce reactive singlet oxygen and strong absorption $\left(>10^{5} \mathrm{M}^{-1} \mathrm{~cm}^{-1}\right)$ at wavelengths between $600-$ $850 \mathrm{~nm}$ (within the so called "phototherapeutic window"). Indeed, at wavelengths far into the red or near infrared regions, the scattering of light is minimal and penetration into tissues can achieve 5$6 \mathrm{~mm}$ depth. ${ }^{5,22}$

During the past decades, many significant advances have been made in the field of PS design. However, many of the sensitizer drawbacks used in the therapeutic procedure have not yet been surpassed. Thus, researchers are constantly seeking to design, synthesize, purify and to characterize new compounds that can be used as PS. ${ }^{23}$

As described in the literature, simple squarylium cyanine dyes, derived from benzothiazole, benzoselenazole and quinoline, have the ability to generate singlet oxygen and have a strong absorption in the "phototherapeutic window". 324 However, the potential application of these dyes as sensitizers for PDT has been poorly explored. ${ }^{3,4,6,24}$ The aim of this work was the synthesis and photochemical characterization of new unsymmetrical aminosquarylium cyanine dyes derived from benzothiazole and quinoline, as well as to evaluate their phototherapeutic potential in vitro. Unsymmetrical aminosquarylium cyanine dyes were chosen for this work because these dyes have in their structure a unit of benzothiazole ring capable of increasing production of singlet oxygen and a moiety of quinoline that shift the maximum absorption wavelength to NIR region. To the best of our knowledge, this class of dyes is not mentioned in the literature.

In this work, we also report the dark toxicity of newly synthesized and characterized dyes, as well as their phototoxicity using HepG2 (human hepatocellular carcinoma cell line) and Caco-2 cells (human colorectal adenocarcinoma cell line) as in vitro models. These two cell lines were chosen as cell models by the following reasons: i) they are adherent epithelial cells, facilitating the exposure to the dyes and the washing steps preventing cell number loss which is relevant for cell viability assessment; ii) these cell models may permit data extrapolation concerning to liver toxicity (upon dye administration), and potential use of PDT to treat colon cancer.

\section{Results and discussion}

\subsection{Chemistry}

The new unsymmetrical aminosquarylium cyanine dyes $\mathbf{1 1}$ and 12, having a benzothiazole and quinoline moieties, were synthesized by a multistep procedure as illustrated in Scheme 1. In the first stage, dibutyl squarate 2 , obtained by refluxing squaric acid (3,4-dihydroxycyclobut-3-en-1,2-dione) (1) in $n$ - $\mathrm{BuOH}^{25}$ was reacted with 3-hexyl-2-methylbenzothiazolium iodide (4), which was obtained by alkylation of the 2-methybenzothiazole (3) with an excess of 1-iodohexane, to obtain the monosubstituted intermediate $\mathbf{5}$. Hydrolysis of this intermediate by a $40 \%$ sodium hydroxide aqueous solution and protonation of the resulting sodium salt with $2 \mathrm{M}$ hydrochloride acid led to the key intermediate monosubstituted squaric acid 6 . $^{26}$ The zwitterionic unsymmetrical squarylium cyanine dye 9 was synthesized by base catalyzed condensation of 6 with the quinoline moiety quaternary salt $\mathbf{8}$, in refluxing $n-\mathrm{BuOH} /$ pyridine. The methylation of the latter with the strong methylating agent $\mathrm{CF}_{3} \mathrm{SO}_{3} \mathrm{CH}_{3}$ (3 eq.), in dry dichloromethane, provided the $O$ methyl derivative $\mathbf{1 0}$ in good yield (89\%).

The desired unsymmetrical aminosquarylium cyanine dyes $\mathbf{1 1}$ and 12 were easily obtained by nucleophilic substitution of the methoxyl group in the four-membered ring of $\mathbf{1 0}$ with ammonia or methylamine, respectively. Finally, we proceeded with the counter-ion exchange, namely trifluoromethanesulfonate anion by iodide anion, upon treatment of a methanolic solution of each dye with $14 \%$ aqueous $\mathrm{KI}$, with the purpose to favor the singlet to triplet state intersystem crossing, that is due to the well-known heavy atom effect. ${ }^{6,27}$

The synthesized squarylium cyanine dyes $\mathbf{9 - 1 2}$ showed narrow and strong absorption $\left(\varepsilon>1-2 \times 10^{5} \mathrm{~cm}^{-1} \mathrm{M}^{-1}\right)$ within the socalled "phototherapeutic window", in the visible and near-infrared region ( $\lambda_{\max } 666-714 \mathrm{~nm}$ ), and because of this property, they offer photosensitizing activity useful for PDT (Table 1). The zwitterionic compound 9 has almost the same $\lambda_{\max }$ as the symmetrical quinoline analogue reported in the literature. ${ }^{3}$ The substituted dyes 10-12 displayed a shift to the blue regarding the corresponding non-substituted dye $\mathbf{9}$, and the most pronounced effect was observed for $O$-methylated derivative $\mathbf{1 0}$. This strong shift has been mentioned in the literature ${ }^{28}$ for symmetrical dyes possessing the benzothiazole and quinoline moieties.

In order to create a more suitable LED system for irradiating the cells, Vis spectra of dyes $\mathbf{9}, \mathbf{1 1}$ and 12, were also recorded in DMEM (Dulbescco's Modified Eagle's Medium), the base medium used in cell culture (Fig. 1). In the latter solvent, spectra of all compounds displayed a significant hypsocromic shift and broadening of absorption spectra probably due to formation of aggregates. ${ }^{29}$ These spectral changes do not invalidate their use in PDT, since the dyes maintain a high absorption in the so-called phototherapeutic window. The shift to the Vis absorption range implies that precautions must be taken when handling these dyes under ambient light.

The IR spectra of 9-12 do not show any evidence of carbonyl absorptions at approximately $1700 \mathrm{~cm}^{-1}$, nor exhibit a strong absorption band in the region of $1600 \mathrm{~cm}^{-1}$, as reported in the literature $^{30,31}$ for symmetrical squarylium and $N$-alkylaminosquarylium dyes possessing the indolenine moiety. The IR spectra for the unsymmetrical aminosquarylium dyes $\mathbf{1 1}$ and $\mathbf{1 2}$ show a weak band around $1630 \mathrm{~cm}^{-1}$ which is similar to that reported in the literature for symmetrical aminosquarylium 

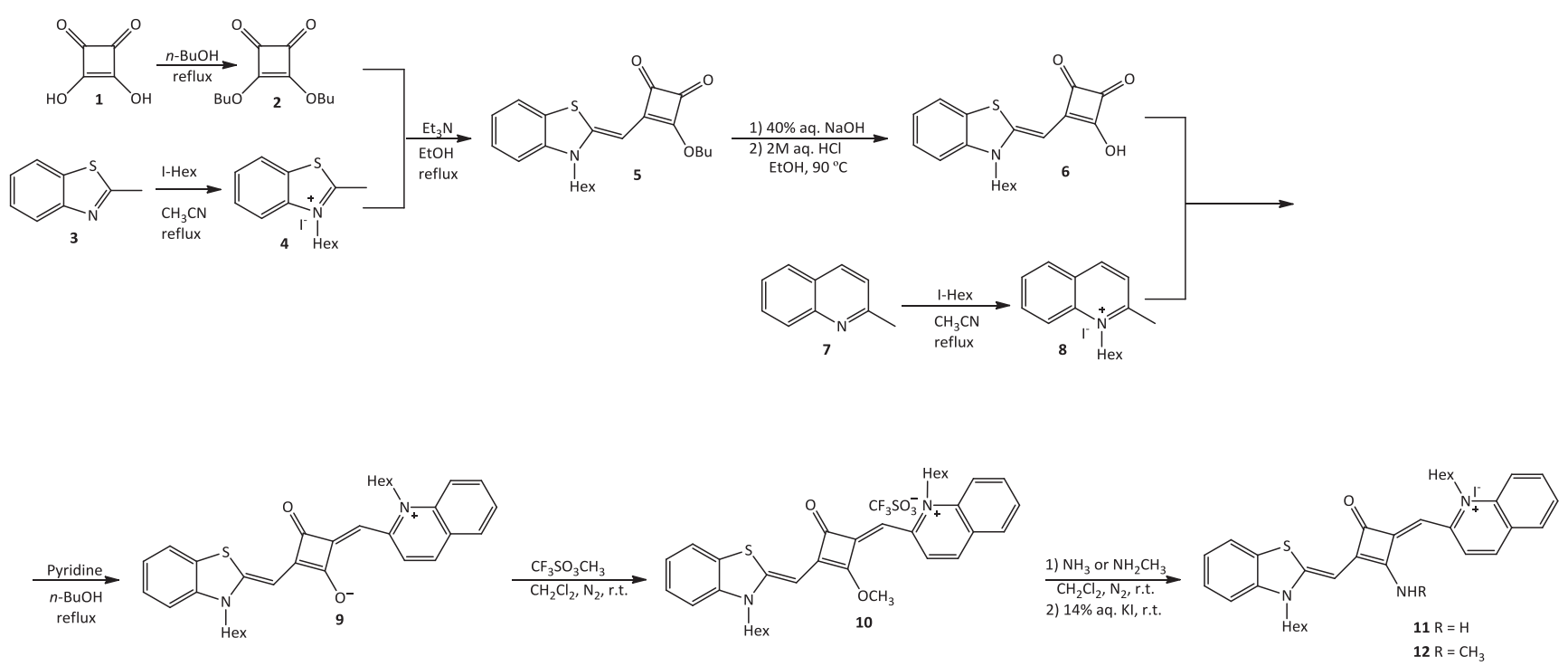

Scheme 1. Synthesis of the unsymmetrical aminosquarylium cyanine dyes $\mathbf{1 1}$ and $\mathbf{1 2}$.

Table 1

The synthesis yield, Vis spectral data and singlet oxygen quantum yields for synthesized squarylium cyanine dyes.

\begin{tabular}{lllll}
\hline Dye & Yield $(\%)$ & $\lambda_{\max }{ }^{\mathrm{a}}[\mathrm{nm}](\log \varepsilon)$ & $\lambda_{\max }{ }^{\mathrm{b}}[\mathrm{nm}]$ & $\Phi \Delta$ \\
\hline $\mathbf{9}$ & 25 & $714(5.06)$ & 627 & 0.03 \\
$\mathbf{1 0}$ & 89 & $666(5.21)$ & - & - \\
$\mathbf{1 1}$ & 70 & $693(5.27)$ & 605 & 0.05 \\
$\mathbf{1 2}$ & 67 & $704(5.17)$ & 631 & 0.04 \\
\hline
\end{tabular}

${ }^{a}$ Measured in DMSO (dimethyl sulfoxide).

b Measured in DMEM (Dulbecco's Modified Eagle's Medium; cell culture medium).

derivatives from benzothiazole and quinoline, ${ }^{24,28,32}$ indicating a strong bonding-delocalization within the four-membered ring system.

The NMR data relevant to the present discussion are summarized in table 2 . The unsymmetrical substitution in the squaraine 9, was confirmed by the presence of two non-equivalent methine protons, in the form of two singlets at 5.87 and $5.83 \mathrm{ppm}$. As expected, the same splitting was observed for dyes 10 and 11. Furthermore, the ${ }^{1} \mathrm{H}$ NMR spectrum of $\mathbf{1 2}$ presented twice the proton signals in relation to their congeners 9-11 suggesting an additional skewness due to the hindered rotation around central $N$-methyl group and therefore a separation of the signals of the methine-protons in four singlets at 5.99, 5.87, 5.84 and $5.74 \mathrm{ppm}$ and in two doublets at 3.29 and $3.26 \mathrm{ppm}$ for the $N$-methyl signals were observed.

The hindrance of free rotation of the $N$-methylamine group, due to the partial character of the double bond between the nitrogen atom and the carbon atom of the four-membered ring, should promote the non-equivalence of chemical environments, and has been previously observed in the NMR spectra of several symmetrical aminosquarylium cyanine dyes. ${ }^{24,28,33}$ The four singlets and the two doublets aforementioned collapsed in two singlets, at 6.03 and 5.97, and in a singlet at $3.36 \mathrm{ppm}$, respectively, when the ${ }^{1} \mathrm{H}$ NMR spectrum was obtained at $363.15 \mathrm{~K}$. The ${ }^{1} \mathrm{H}$ NMR spectrum of 12 at the latter temperature presents half of the signals of spectrum recorded at $298.15 \mathrm{~K}$. We conclude that at higher temperature no restriction to the free rotation of the referred $\mathrm{C}-\mathrm{N}$ bond has been observed.

As expected, the ${ }^{13} \mathrm{C}$ NMR spectra of 9-11 displayed two different signals (93.9-84.7) for the corresponding methine-carbons resulting from two different heterocyclic rings bound to the central four-membered ring (Table 2). However, the ${ }^{13} \mathrm{C}$ NMR spectrum of 12 presents four signals in the range 94.3-85.8 ppm instead of two. This fact confirms, once again, the possibility of the existence of two configurations at room temperature, resulting from the hindrance to free rotation of the aforementioned $\mathrm{C}-\mathrm{N}$ bond.

The singlet oxygen formation quantum yields of the unsymmetrical squarylium dyes synthesized $\mathbf{9 , 1 1}$ and $\mathbf{1 2}$ (Table 1 ) are very low (0.03-0.05). However, low singlet oxygen quantum yields are typical for symmetrical aminosquarylium cyanine dyes derivatives from benzothiazole ${ }^{6}$, and can be interpreted in terms of efficient deactivation of the excited squaraine dye via fluorescence, internal conversion and photoisomerization.

A high yield of singlet oxygen formation by PS is expected when predicting its toxicity after photo-activation as it is one of the most relevant ROS in biological systems, presenting a pivotal role on PDT. ${ }^{34}$ But, there are reports of cyanine dyes with low singlet oxygen yield that show good phototoxicity results, i.e. toxicity development after appropriate irradiation and in higher extent than that observed under dark conditions. As example, Delaey and coworkers (2000) studied a set of cyanine dyes that produced singlet oxygen yields lower than 0.08 (which are considered very low in PDT) but that showed good photo-dependent anti-proliferative results in HeLa cells. These authors observed a reduction on cell viability up to 22-fold, after irradiation $\left(\mathrm{CC}_{50}=9.1 \mu \mathrm{M}\right.$ in dark versus $0.41 \mu \mathrm{M}$ after irradiation). ${ }^{35}$ Thus, although the synthesized dyes $(\mathbf{9}, 11$ and 12) produce low singlet oxygen quantum yields, we decided to proceed with the in vitro studies, to assess the phototherapeutic potential of these new unsymmetrical squarylium cyanine dyes.

\subsection{Evaluation of photosensitizing potential of synthesized dyes}

As stated above, the main attribute of a PS to be consider for PDT is to produce no dark toxicity (or at a minimal extent) when in contact with cells or tissues, but when appropriately irradiated it provides a sequence of reactions that culminate with cell death.

In this study, the toxicity of the different dyes was evaluated by the Alamar Blue (AB) reduction assay, using HepG2 and Caco-2 cell, as described in methods (section 4.3.3). Caco-2 or HepG2 cells were exposed to different concentrations of dyes $\mathbf{9 ,} \mathbf{1 1}$ or $\mathbf{1 2}$ for $24 \mathrm{~h}$ (incubation period). After that, cells were submitted to three 
A
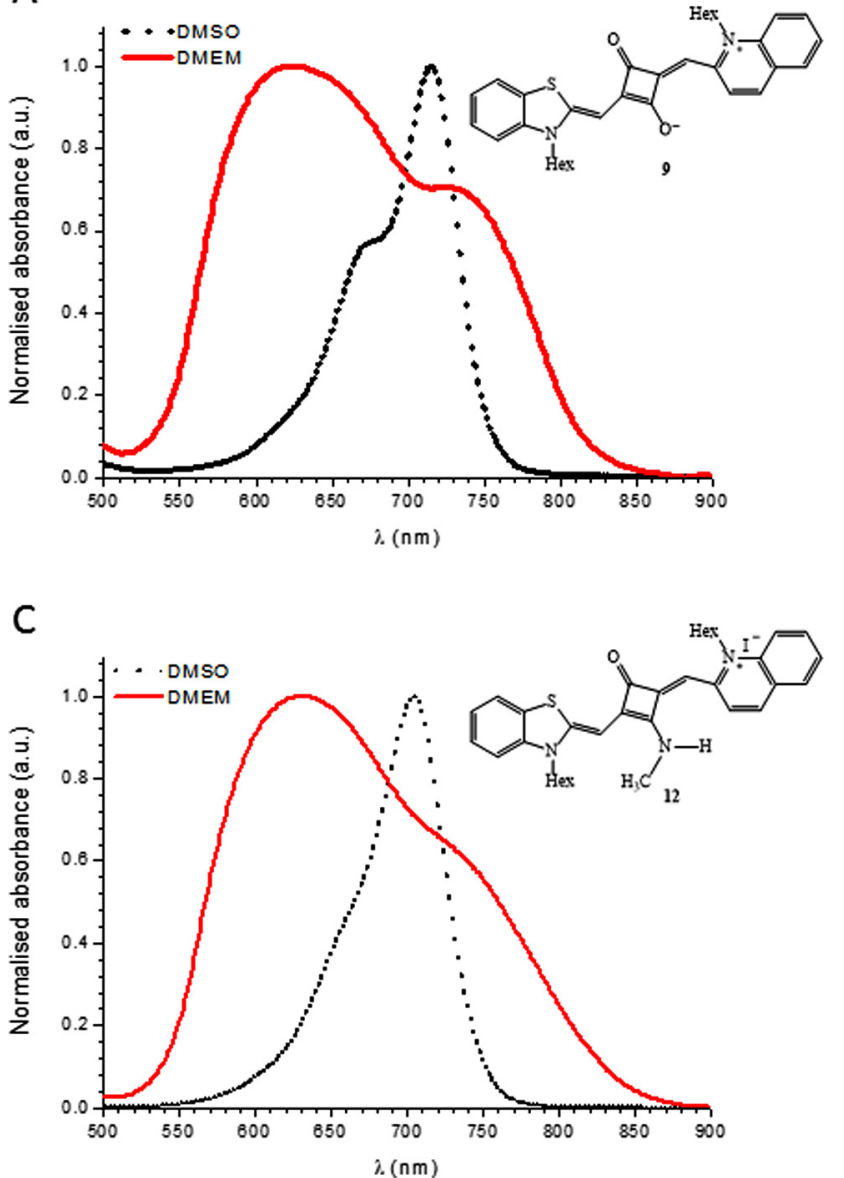

B
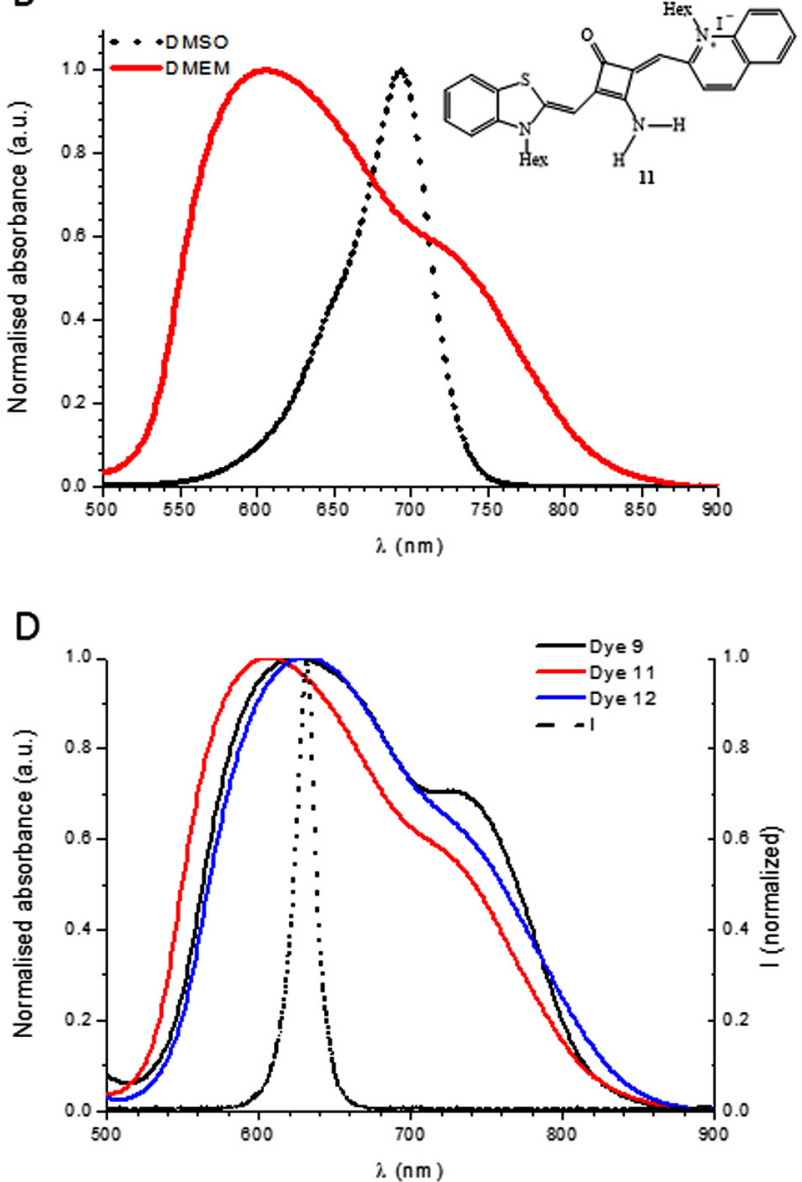

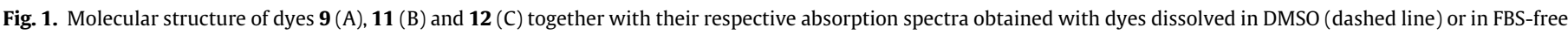

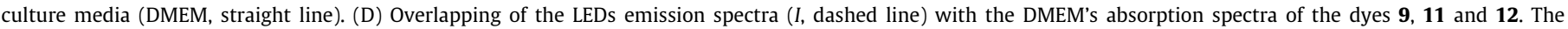
absorbance and the current $(I)$ was normalized and are present as arbitrary units (a.u.).

Table 2

Relevant NMR spectra data for dyes 9-12.

\begin{tabular}{llll}
\hline \multirow{2}{*}{ Dye } & \multicolumn{1}{l}{${ }^{1} \mathrm{H}$ NMR } & & ${ }^{13} \mathrm{CNMR}^{\mathrm{a}}$ \\
\cline { 2 - 3 } & $\mathrm{C}=\mathrm{C} \underline{\mathrm{H}}$ & $\mathrm{NC}_{3}$ & $\mathrm{C}=\underline{\mathrm{C}} \mathrm{H}$ \\
\hline $\mathbf{9}$ & $5.87(1 \mathrm{H}, \mathrm{s})$ & - & 92.6 \\
& $5.83(1 \mathrm{H}, \mathrm{s})$ & & 84.7 \\
$\mathbf{1 0}$ & $6.00(1 \mathrm{H}, \mathrm{s})$ & - & 92.1 \\
& $5.65(1 \mathrm{H}, \mathrm{s})$ & & 85.3 \\
$\mathbf{1 1}$ & $6.01(1 \mathrm{H}, \mathrm{s})$ & - & 93.9 \\
& $5.87(1 \mathrm{H}, \mathrm{s})$ & & 85.6 \\
$\mathbf{1 2}^{\mathrm{a}}$ & $5.99(1 \mathrm{H}, \mathrm{s})$ & $3.29(3 \mathrm{H}, \mathrm{d}, J=4.2 \mathrm{~Hz})$ & 94.3 \\
& $5.87(1 \mathrm{H}, \mathrm{s})$ & $3.26(3 \mathrm{H}, \mathrm{d}, J=3.6 \mathrm{~Hz})$ & 93.9 \\
& $5.84(1 \mathrm{H}, \mathrm{s})$ & & 85.9 \\
& $5.74(1 \mathrm{H}, \mathrm{s})$ & & 85.8 \\
$\mathbf{1 2}^{\mathrm{b}}$ & $6.03(1 \mathrm{H}, \mathrm{s})$ & $3.36(3 \mathrm{H}, \mathrm{s})$ & - \\
& $5.97(1 \mathrm{H}, \mathrm{s})$ & &
\end{tabular}

NMR spectra obtained in the solvents: $\mathbf{9}\left(\mathrm{CDCl}_{3}+\mathrm{CD}_{3} \mathrm{OD}\right) ; \mathbf{1 0}\left(\mathrm{CDCl}_{3}\right) ; \mathbf{1 1 - 1 2}$ (DMSO- $d_{6}$ ).

a NMR spectra obtained at $298.15 \mathrm{~K}$

b ${ }^{1} \mathrm{H}$ NMR spectrum obtained at $363.15 \mathrm{~K}$.

different conditions: i) without irradiation (0 min), the 96-wellplate was removed from the incubator and left in the dark at room temperature for $14 \mathrm{~min}$ (temperature and $\mathrm{CO}_{2}$ conditions identical to those of the irradiated cells; non-irradiated control); ii) 7 min of irradiation with LEDs centred at $630 \mathrm{~nm}$; cells were kept deprived from environment light, at room temperature and outside of incubator; iii) 14 min of irradiation, in the same conditions as previous.
After irradiation, cells were left in contact with irradiated dyes for $1 \mathrm{~h}$ or $24 \mathrm{~h}$, to test the effect of exposure time on cell viability, condition that will be analysed on the cell viability assays. Figs. 3-5 show the results of cell viability at $1 \mathrm{~h}$ or $24 \mathrm{~h}$ after irradiation, as well as the results of cells that were left under dark conditions, in which the time after dark period exposure ( 0 min irradiation) has been counted. After this period ( $1 \mathrm{~h}$ or $24 \mathrm{~h}$ ) all cells were treated in the same way.

\subsubsection{Dark toxicity assessment}

Fig. 2 shows the results of Caco-2 (Fig. 2A, B and C) and of HepG2 (Fig. 2A', $B^{\prime}$ and $C^{\prime}$ ) cells exposed to dyes 9, 11 and 12, in dark condition, to assess the inherent toxicity of the dyes (dark toxicity). In this study, the effect of the solvent used to solubilize dye $\mathbf{9}$ (mixture of DMSO/ $\mathrm{CH}_{2} \mathrm{Cl}_{2} ; 24: 1$ ) was also tested in separate experiments, on both cell lines, using equivalent solvent volumes as those of tested dye, (Fig. $2 \mathrm{~A}$ and $\mathrm{A}^{\prime}$ ). The observed reduction on cell viability (Fig. 2A and $A^{\prime}$ ) is probably due to the effect of solvent and not to the dye $\mathbf{9}$, as the same cytotoxic profile was observed for the solvent exposure alone and for compound. In the dissolution of the dyes $\mathbf{1 1}$ and 12, only DMSO was used, its concentration was always kept below 3\% (these cells exposed to DMSO concentrations up to $5 \%$ maintain cell viability in values that are not different from non-exposed cells, data not shown). Concerning the toxicity effect of the dyes, exposure of Caco-2 and HepG2 cells to dyes 9, 11 and 12, at concentrations ranging from 0.1 to $10 \mu \mathrm{M}$, revealed that dyes $\mathbf{1 1}$ and $\mathbf{1 2}$ are the most toxic, reducing the cell 
A

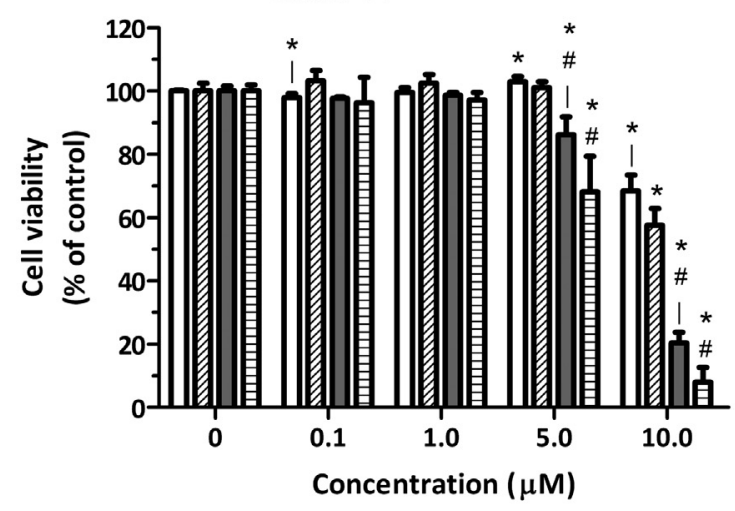

B

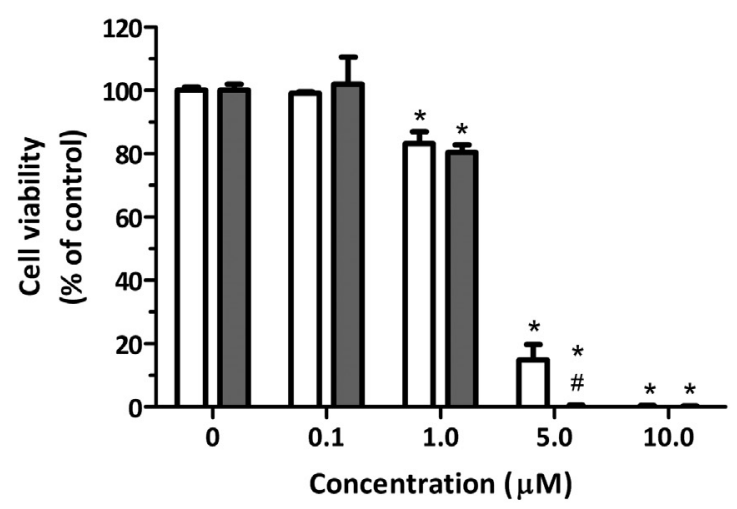

C

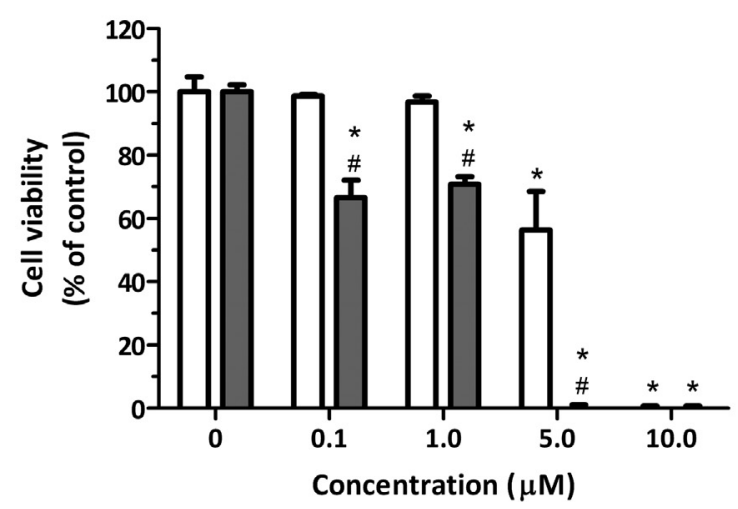

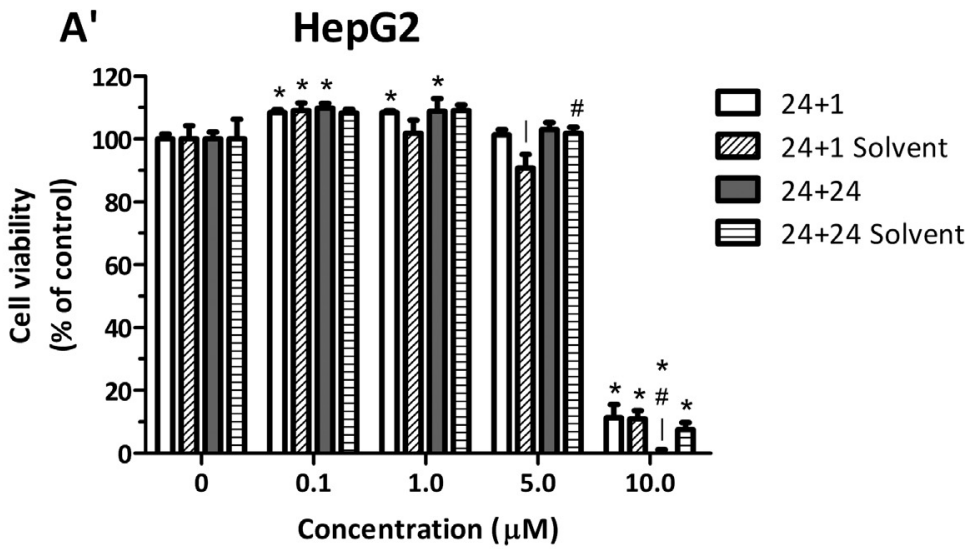

B'

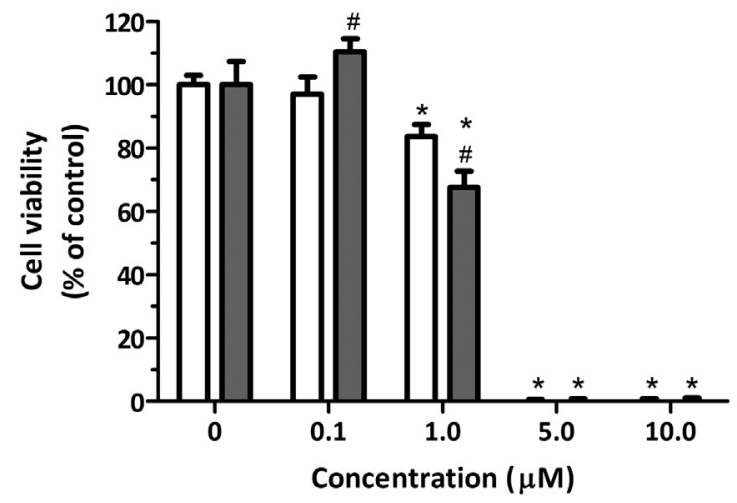

$\mathbf{C}^{\prime}$

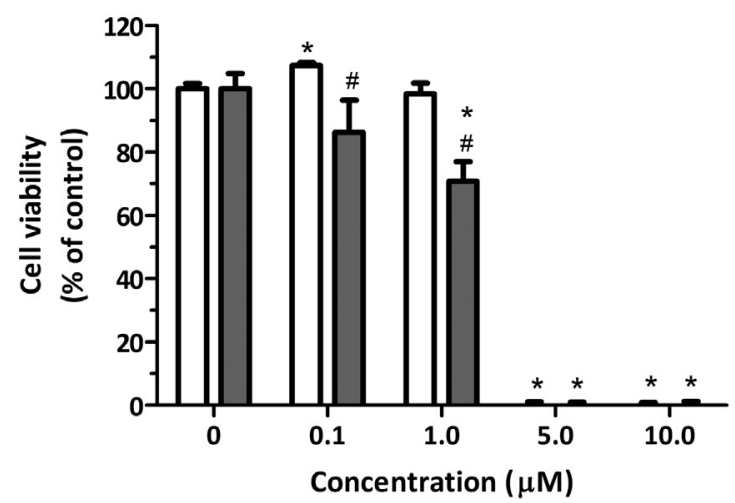

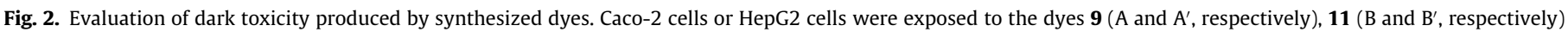

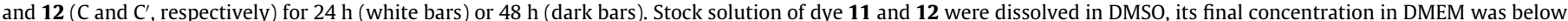

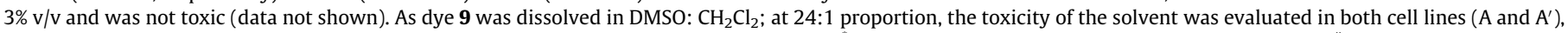

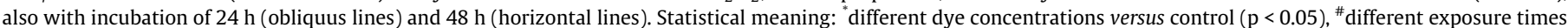

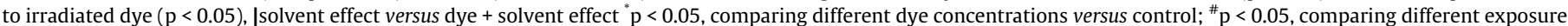
times to irradiated dye; $\mathrm{p}<0.05$, comparing solvent effect versus dye + solvent effect.

viability down to approx. $0 \%$ at 5 and $10 \mu \mathrm{M}$ (dye $\mathbf{1 1}$ and $\mathbf{1 2}$, Fig. 2B, $\mathrm{B}^{\prime}, \mathrm{C}$ and $\mathrm{C}^{\prime}$ ). Exposure of cells to dye $\mathbf{9}$, revealed lower toxicity to both cell lines, although $10 \mu \mathrm{M}$ reduced HepG2 cell viability down to approx. $15 \%$ of control while Caco-2 cells, at this concentration, were more resistant (Fig. $2 \mathrm{~A}$ and $\mathrm{A}^{\prime}$ ). At $1.0 \mu \mathrm{M}$, dye $\mathbf{9}$ is non-toxic (Fig. 2A and $A^{\prime}$ ), but dye $\mathbf{1 1}$ (Fig. 2B and $B^{\prime}$ ) reduced cell viability by about $20 \%$ which increased with exposure time in HepG2 cells (Fig. 2B'). With regard to dye 12, it became slightly toxic (viability $\approx 70 \%$ ) at $0.1 \mu \mathrm{M}$ and $1.0 \mu \mathrm{M}$ in Caco-2 cells
(Fig. 2C) and at concentration of $1.0 \mu \mathrm{M}$ in HepG2 cells (Fig. $2 \mathrm{C}^{\prime}$ ) when the exposure time to the dye was increased.

Fadda and El-Mekawy (2013) tested the anticancer activity of a set of cyanine dyes on several cell lines, including HepG2 cells, by incubating the cells for $96 \mathrm{~h}$, in dark conditions. The authors recorded $\mathrm{IC}_{50}$ values ranging from 8 to $70 \mu \mathrm{g} / \mathrm{mL}$, which are 2- to 20 -fold higher than ours, and considered to have week to moderate anticancer activity. ${ }^{36}$ Squaraines bearing halogenated moieties have been reported to show concentration dependent toxicity. 
Exposure to concentrations up to $10 \mu \mathrm{M}$ were cytotoxic to HT-1080 cells at $24 \mathrm{~h}$, while concentrations in the rage of $1-2 \mu \mathrm{M}$ (values that are in the same range as ours) were non-cytotoxic. ${ }^{37}$

\subsubsection{Cell viability assessment after dye irradiation}

In order to assess the potential application of the synthesized dyes as PS, the cells previously incubated with the dyes (for $24 \mathrm{~h}$ ), were irradiated with LEDs centred at $630 \mathrm{~nm}$. This self-made apparatus allowed the irradiation of each well with the same light intensity and avoiding partial dispersion of light, which may occur when illuminating the 96 -well plate with the same lamp.
Irradiation was performed using two different periods, i.e. during $7 \mathrm{~min}$ or $14 \mathrm{~min}$, using different cells. After the irradiation period, cells were placed in the incubator for $1 \mathrm{~h}$ or $24 \mathrm{~h}$, to allow the contact of cells with irradiated compounds, and then were washed with phosphate buffered solution (PBS) and cell viability was assessed (cell viability has been reported at $1 \mathrm{~h}$ or $24 \mathrm{~h}$, with reference to irradiation time).

The irradiation effect produced in Caco- 2 cells viability is illustrated in Fig. 3. For dye $\mathbf{9}$ (Fig. $3 \mathrm{~A}$ and $\mathrm{A}^{\prime}$ ), irradiation produced only a slight decreased on cell viability, which increases with irradiation time and with the time of exposure to the irradiated dye and, being
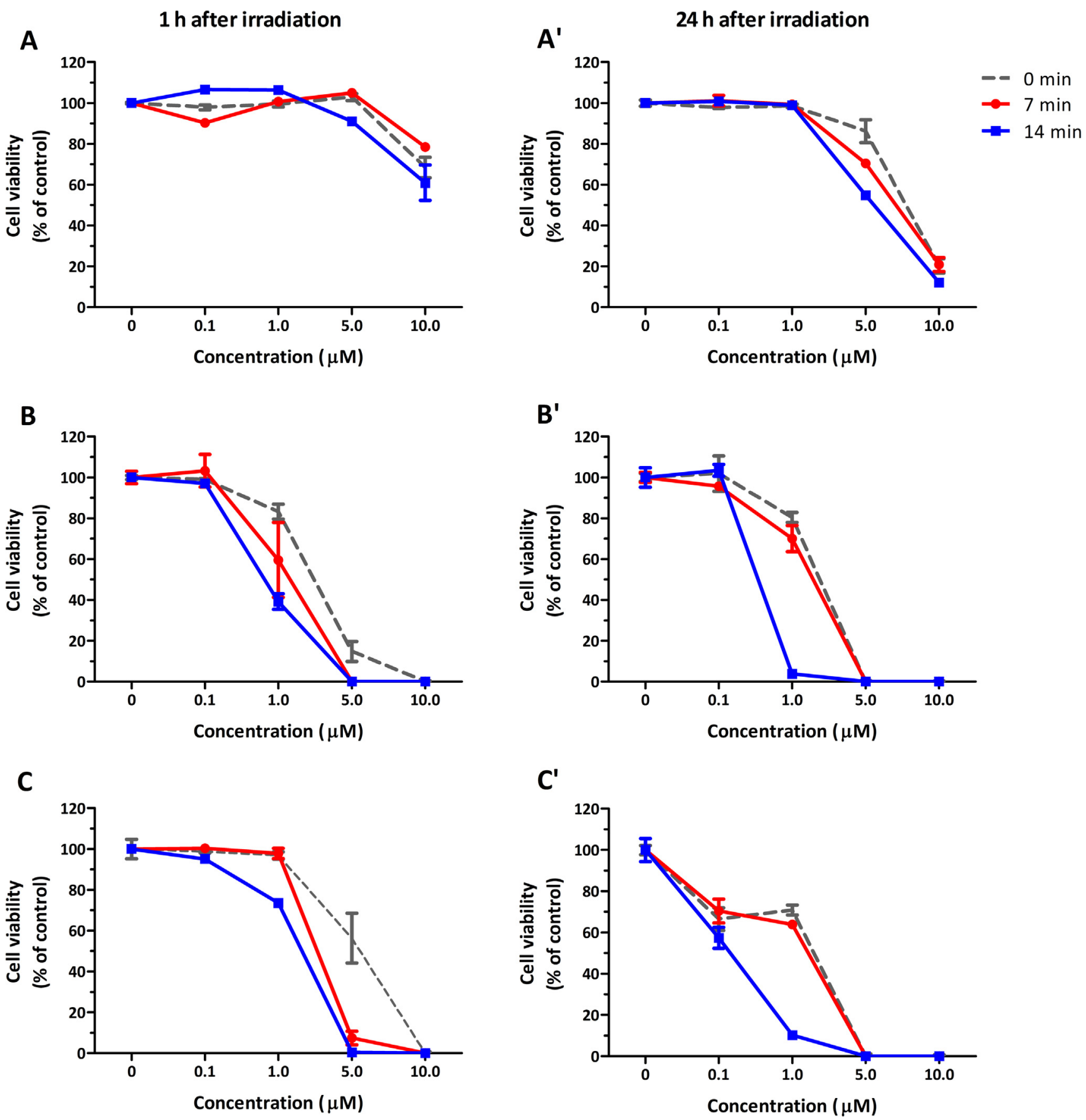

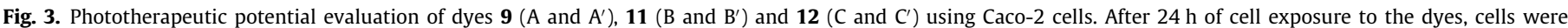

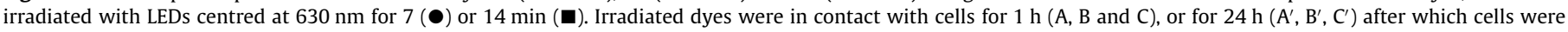
washed and cell viability was evaluated using the Alamar blue assay (see methods for details). 
Table 3

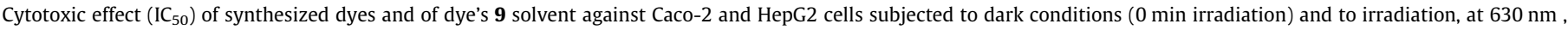
during 7 or 14 min. Dye 9 was dissolved in DMSO: $\mathrm{CH}_{2} \mathrm{Cl}_{2}$ (24:1).

\begin{tabular}{|c|c|c|c|c|c|c|c|}
\hline \multicolumn{8}{|l|}{$\mathrm{IC}_{50}(\mu \mathrm{M})$} \\
\hline \multirow[t]{2}{*}{ Dye } & \multirow[t]{2}{*}{ Time } & \multicolumn{2}{|c|}{$0^{\prime}$ of irradiation (dark) } & \multicolumn{2}{|c|}{$7^{\prime}$ of irradiation } & \multicolumn{2}{|c|}{$14^{\prime}$ of irradiation } \\
\hline & & Caco-2 & HepG2 & Caco-2 & HepG2 & Caco-2 & HepG2 \\
\hline \multirow[t]{2}{*}{9} & $1 \mathrm{~h}$ & $>10$ & 9.10 & $>10$ & 8.53 & $>10$ & 8.95 \\
\hline & $24 \mathrm{~h}$ & 5.80 & 7.84 & 5.38 & 8.24 & 5.08 & 5.06 \\
\hline \multirow[t]{2}{*}{11} & $1 \mathrm{~h}$ & 1.72 & 1.71 & 1.24 & 0.75 & 0.95 & 0.86 \\
\hline & $24 \mathrm{~h}$ & 1.65 & 1.40 & 1.39 & 0.94 & 0.69 & 0.65 \\
\hline \multirow[t]{2}{*}{12} & $1 \mathrm{~h}$ & 5.11 & 2.93 & 3.90 & 3.39 & 1.46 & 0.93 \\
\hline & $24 \mathrm{~h}$ & 1.27 & 1.36 & 1.16 & 1.02 & 0.47 & 0.83 \\
\hline \multirow[t]{2}{*}{ Solvent of dye $\mathbf{9}$} & $1 \mathrm{~h}$ & $>10$ & 5.99 & - & - & - & - \\
\hline & $24 \mathrm{~h}$ & 5.33 & 8.91 & - & - & - & - \\
\hline
\end{tabular}

evident only for $5 \mu \mathrm{M}(\mathrm{p}<0.05)$, as at $10 \mu \mathrm{M}$ inherent toxicity $(p<0.05)$ of the dye is already observed (Fig. $\left.3 A^{\prime}\right)$. Dyes 11 and 12 (Fig. 3B, $\mathrm{B}^{\prime}, \mathrm{C}$ and $\mathrm{C}^{\prime}$ ) produced a better photodynamic behaviour (area between lines), which is also dependent on the irradiation period and time of exposure to irradiated dye. A phototherapeutic effect was observed at $1 \mu \mathrm{M}$ of dye 11, with 14 min of irradiation and after $24 \mathrm{~h}$ in contact with the irradiated dye (Fig. 3B'), this condition reduces cell viability from $\sim 80 \%$ of control to about $0 \%$. An irradiation period of $7 \mathrm{~min}$ was also shown to be too short because only a slight reduction on the viability was observed in comparison to non-irradiated cells, as can be observed in Table 3, with $\mathrm{IC}_{50}$ ' that are very similar. The contact with irradiated dye for $1 \mathrm{~h}$ was also shown to be too short (Fig. 3B). Concerning dye 12, this has a lower inherent toxicity, comparing to dye $\mathbf{1 1}$ (Fig. 3C; Table 3), and some phototoxic activity was observed at $5 \mu \mathrm{M}(\mathrm{p}<0.05)$ with both irradiation periods (Fig. 3 C), i.e. a decrease on cell viability from $\sim 60 \%$ to near zero. Longer contact with irradiated dye provided a phototoxic effect at $1 \mu \mathrm{M}$ (Fig. $3 \mathrm{C}^{\prime}$ ), while at higher concentrations is already toxic. In Caco-2, the dye that exhibits the best potential to be used as PS is dye $\mathbf{1 2}$, as it shown a high $\mathrm{IC}_{50}$ at dark conditions $(5.11 \mu \mathrm{M})$ that decreases about 3.6-times after exposure for $1 \mathrm{~h}$ to the irradiated dye (irradiation for $14 \mathrm{~min}$ ) (Table 3 ).

Concerning the effect on HepG2 cells, irradiated dye $\mathbf{9}$ has the same toxicity as the non-irradiated, when exposed for $1 \mathrm{~h}$ (Fig. 4A), but longer exposure to irradiated dye (Fig. 4A') decreased the cell viability $(\mathrm{p}<0.05$ ), but only with $5 \mu \mathrm{M}$ of dye after $14 \mathrm{~min}$ of irradiation (Fig. 4A'). Dyes $\mathbf{1 1}$ and $\mathbf{1 2}$ (Fig. 4B and C), are more toxic, but also toxicity increased with irradiation $(\mathrm{p}<0.05)$. However, exposure to irradiated dye for $1 \mathrm{~h}$ produced some phototoxic effect, especially at $1 \mu \mathrm{M}$, but dye 11 (Fig. 4B) showed about the same phototoxicity with 7 or 14 min of irradiation while dye 12 (Fig. 4C) was shown to be phototoxic only with 14 min irradiation. Longer exposures to irradiated dyes resulted in some phototoxicity. Indeed, $5 \mu \mathrm{M}$ of dye 9, after $14 \mathrm{~min}$ of irradiation (Fig. $4 \mathrm{~A}^{\prime}$ ) reduced cell viability in about $50 \%$, whereas irradiated dye $\mathbf{1 1}$ and 12 only produced a small decrease $(\mathrm{p}<0.05)$ on HepG2 cell viability at concentration of $1.0 \mu \mathrm{M}$, since higher concentrations have already dark toxicity (Fig. $4 \mathrm{~B}, \mathrm{~B}^{\prime}, \mathrm{C}$ and $\mathrm{C}^{\prime}$ and Table 3 ).

Our data is in agreement with that reported by Delay and coworkers (2000), where they show that cyanine dyes with very low singlet oxygen yields produce phototoxicity in HeLa cells, as we report here for Caco-2 and HepG2 cells. Similar phototoxicity was reported in HT-1080 cells after exposure to several squaraine dyes and irradiated with a light beam at $15 \mathrm{~mW} / \mathrm{cm}^{2}$ for $20 \mathrm{~min} .{ }^{37}$ The exact mechanism of PDT induced cell damage is not clear yet, but it has been proposed that both type I and type II reactions are involved in the process and can damage cellular constituents, such as lipids, proteins or DNA, and eventually cause cell death. It has been accepted that type II reaction (singlet oxygen) is the main responsible for inducing cell death. ${ }^{5}$

Production of ROS had been proposed as a major trigger of cell death in PDT by initiating the apoptosis cascade. Increase of ROS production was measured after irradiation of Ehrlich's Ascites Carcinoma (EAC) cells, pre-treated with symmetrical diiodinated benzothiazolium squarylium dye, SQDI. ${ }^{38}$ Serpe et al. (2016) observed an increase of ROS production, on human fibrosarcoma (HT-1080) cell line exposed squarylium dyes, and verified that necrosis was the main cell death pathway induced by irradiation. Although an increase in ROS is expected after irradiation of cells pre-exposed to photosensitizers, the mechanism by which PDT induces cell death is still under study. Therefore, with the results herein presented, we believe that, for these three squaraine dyes, the type I reaction is the main pathway involved in the PDT action, although further studies are being currently carried out.

\section{Conclusions}

In this work, three new unsymmetrical squarylium cyanine dyes derived from benzothiazole and quinoline were synthesized and their potential application for photodynamic therapy was evaluated. The synthesis of these dyes was shown to be simple and with moderate yields. The toxicity of the synthesized dyes was evaluated by Alamar Blue reduction assay, using HepG2 and Caco-2 cells. Reduction on cell viability was shown to be dependent on the dye concentration and exposure time.

Although singlet oxygen formation quantum yields were very low, the in vitro results demonstrated the photosensitizing potential of these dyes as photosensitizers, being worth to be improved in order to reduce dark toxicity so that they can also be tested in vivo.

\section{Experimental}

\subsubsection{Chemistry. General methods}

All solvents, of analytical grade, and reagents (i.e. squaric acid (1); 2-methylbenzothiazole (3); 2-methylquinoline (7)) were purchased from commercial sources and used as received without further purification, unless otherwise stated. Petroleum ether refers to the fraction $40-60{ }^{\circ} \mathrm{C}$. Anhydrous solvents were dried, as described in the literature ${ }^{39}$ and freshly distilled. 3-hexyl-2-methylbenzothiazol-3-ium iodide (4) and 1-hexyl-2-methylquinolin-1-ium iodide (8) were prepared according to the literature procedure. ${ }^{40}$ Purification by column chromatography was carried out on silica gel 60 (70-230 mesh) using a mixture of ethyl acetate and petroleum 

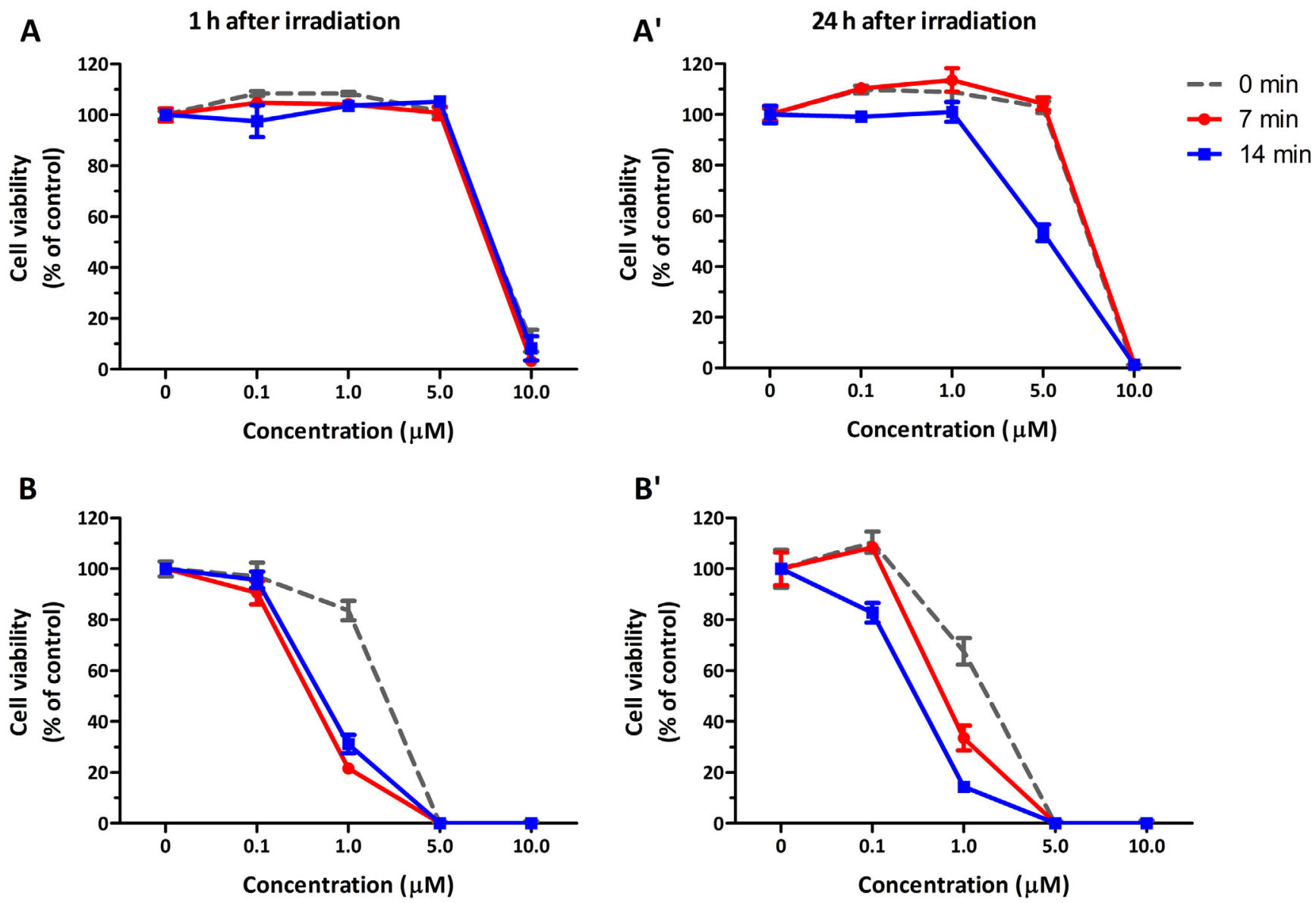

C

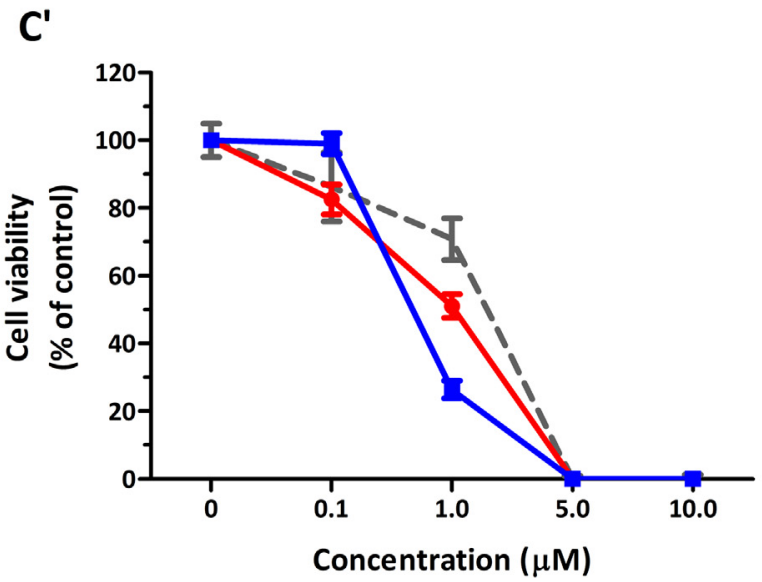

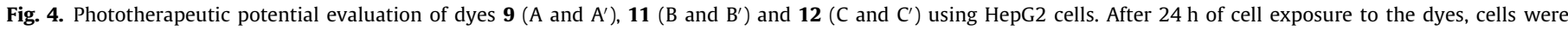

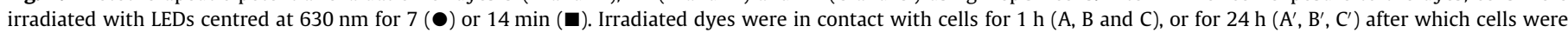
washed with PBS and cell viability was evaluated using the Alamar blue assay (see methods for details).

ether (1:1) as eluent. Recrystallizations were carried out in solvent mixtures mentioned in each case. Analytical thin-layer chromatography (TLC) was conducted on aluminium plates with $0.25 \mathrm{~mm}$ of silica gel (Merck $60 \mathrm{~F}_{254}$ ). Melting points $(\mathrm{Mp})$ were determined in a hot plate binocular microscope apparatus and were not corrected. ${ }^{25}{ }^{1} \mathrm{H}$ and ${ }^{13} \mathrm{C}$ NMR spectra were recorded at $298.15 \mathrm{~K}$, unless otherwise stated, on an NMR Brücker Avance III 400 spectrometer operating at $9.4 \mathrm{~T}$, observing ${ }^{1} \mathrm{H}$ at $400.13 \mathrm{MHz}$ and ${ }^{13} \mathrm{C}$ at $100.63 \mathrm{MHz}$ or on an NMR Brücker Avance III 600 spectrometer operating at $14.09 \mathrm{~T}$, observing ${ }^{1} \mathrm{H}$ at 600.13 and ${ }^{13} \mathrm{C}$ at
150.91 MHz. Solutions were prepared in $\mathrm{CDCl}_{3}$, DMSO- $d_{6}$, in a mixture of $\mathrm{CDCl}_{3}$ and $\mathrm{CD}_{3} \mathrm{OD}$, or in a mixture of $\mathrm{CDCl}_{3}$ and DMSO- $d_{6}$ (as denoted in next section). The chemical shifts are expressed as $\delta$ ( $\mathrm{ppm}$ ) relative to tetramethylsilane (internal standard) or to residual solvent signals and $J$ values are given in hertz $(\mathrm{Hz})$. The assignments of the carbons were made based on DEPT 90 and DEPT 135 spectra. Vis spectra were measured on a Perkin-Elmer Lambda 25 instrument; $\lambda_{\max }$ in nanometers $(\mathrm{nm})$. Infra-red (IR) spectra were recorded on a UNICAM Research Series FTIR spectrophotometer; $v_{\max }$ in $\mathrm{cm}^{-1}$. High resolution electrospray ionization time-of-flight 
mass spectra (HRESI-TOFMS) were recorded using a microTOF (focus) Brücker Daltonics spectrometer (University of Vigo).

\subsubsection{Synthesis of 3,4-dibutoxycyclobut-3-en-1,2-dione (2)}

A solution of squaric acid (1) $(2.00 \mathrm{~g}, 17.54 \mathrm{mmol})$ in $n$-BuOH $(50 \mathrm{~mL})$ was refluxed under stirring for $3 \mathrm{~h}$. After cooling on an ice bath, $50 \mathrm{~mL}$ of diethyl ether $\left(\mathrm{Et}_{2} \mathrm{O}\right)$ was added to the mixture, which was sequentially washed with cold distilled water, cold saturated aqueous $\mathrm{NaHCO}_{3}$, and cold distilled water. The organic layer, after separation, was dried over anhydrous sodium sulphate and the solvent removed under reduced pressure. The resulting brownish oil ( $2.92 \mathrm{~g}, 74 \%$ yield) was chromatographically pure and used in the next reaction without further purification. Yield: $74 \%$.

\subsubsection{Synthesis of 3-butoxy-4-[(3-hexylbenzothiazol-2(3H)-ylidene)} methyl]-cyclobut-3-en-1,2-dione (5)

A mixture of 2 (3.88 g, $17.17 \mathrm{mmol})$ and $4(6.21 \mathrm{~g}, 17.17 \mathrm{mmol})$ in $\mathrm{EtOH}(120 \mathrm{~mL})$ was heated under reflux for $5 \mathrm{~h}$, in the presence of $\mathrm{Et}_{3} \mathrm{~N}$ (2.63 mL, $\left.20.00 \mathrm{mmol}\right)$. After cooling at room temperature the mixture was kept on an ice bath allowing the product to precipitate. The crude product was filtered under reduced pressure and purified by column chromatography using a mixture of ethyl acetate and petroleum ether $(1: 1)$ as eluent. Yellow crystals (2.54 g, 38\% yield). Mp $119-121^{\circ} \mathrm{C}$. IR (KBr) $v_{\text {max }}$ : 2954, 2931, $1766,1702,1545,1485,1467,1415,1346,1309,1273,1187$, 749. ${ }^{1} \mathrm{H}$ NMR $\left(600.13 \mathrm{MHz}, \mathrm{CDCl}_{3}\right) \delta: 7.49(1 \mathrm{H}, \mathrm{d}, J=7.8, \mathrm{Ar}-\mathrm{H})$, $7.34(1 \mathrm{H}, \mathrm{t}, J=7.8, \mathrm{Ar}-\mathrm{H}), 7.16(1 \mathrm{H}, \mathrm{t}, J=7.5, \operatorname{Ar}-\mathrm{H}), 7.06(1 \mathrm{H}, \mathrm{d}$, $J=8.4, \operatorname{Ar}-\mathrm{H}), 5.46(1 \mathrm{H}, \mathrm{s}, \mathrm{C}=\mathrm{CH}), 4.81\left(2 \mathrm{H}, \mathrm{t}, J=6.9, \mathrm{OCH}_{2}\left(\mathrm{CH}_{2}\right)_{2}\right.$ $\left.\mathrm{CH}_{3}\right), 3.97\left(2 \mathrm{H}, \mathrm{t}, J=7.8, \mathrm{NCH}_{2}\left(\mathrm{CH}_{2}\right)_{4} \mathrm{CH}_{3}\right), 1.86$ (2H, quint, $J=7.2$, $\mathrm{OCH}_{2} \mathrm{CH}_{2} \mathrm{CH}_{2} \mathrm{CH}_{3}$ ), 1.78 (2H, quint, $J=7.8, \mathrm{NCH}_{2} \mathrm{CH}_{2}\left(\mathrm{CH}_{2}\right)_{3} \mathrm{CH}_{3}$ ), $1.52\left(2 \mathrm{H}\right.$, sext, $\left.\mathrm{O}\left(\mathrm{CH}_{2}\right)_{2} \mathrm{CH}_{2} \mathrm{CH}_{3}\right), 1.45$ (2H, quint, $J=7.8, \mathrm{~N}\left(\mathrm{CH}_{2}\right)_{2}$ $\left.\mathrm{CH}_{2}\left(\mathrm{CH}_{2}\right)_{2} \mathrm{CH}_{3}\right), 1.39-1.31\left(4 \mathrm{H}, \mathrm{m}, \mathrm{N}\left(\mathrm{CH}_{2}\right)_{3}\left(\mathrm{CH}_{2}\right)_{2} \mathrm{CH}_{3}\right), 1.00(3 \mathrm{H}, \mathrm{t}$, $\left.J=7.5, \mathrm{O}\left(\mathrm{CH}_{2}\right)_{3} \mathrm{CH}_{3}\right), 0.91\left(3 \mathrm{H}, \mathrm{t}, J=6.9, \mathrm{~N}\left(\mathrm{CH}_{2}\right)_{5} \mathrm{CH}_{3}\right) .{ }^{13} \mathrm{C} \mathrm{NMR}$ $\left(150.91 \mathrm{MHz}, \mathrm{CDCl}_{3}\right) \delta: 193.2,186.0,185.6,172.9,159.7,141.3$, 127. (Ar- $\underline{\mathrm{CH}}), 126.9,123.7$ ( $\mathrm{Ar}-\underline{\mathrm{CH}}), 122.2(\mathrm{Ar}-\underline{\mathrm{CH}}), 111.1(\mathrm{Ar}-\underline{\mathrm{CH}})$, $79.2(\mathrm{C}=\underline{\mathrm{CH}}), 73.7\left(\mathrm{OCH}_{2}\right), 46.0\left(\mathrm{NCH}_{2}\right), 32.3\left(\underline{\mathrm{CH}}_{2}\right), 31.6\left(\underline{\mathrm{CH}}_{2}\right)$, $26.9\left(\underline{\mathrm{CH}}_{2}\right), 26.8\left(\underline{\mathrm{CH}}_{2}\right), 22.7\left(\underline{\mathrm{CH}}_{2}\right), 18.9\left(\underline{\mathrm{CH}}_{2}\right), 14.2\left(\underline{\mathrm{CH}}_{3}\right), 13.9$ $\left(\mathrm{CH}_{3}\right)$. ESI-TOFMS $m / z: 386.18[\mathrm{M}+\mathrm{H}]^{+}$.

4.1.4. Synthesis of 3-[(3-hexylbenzothiazol-2(3H)-ylidene)methyl]-4hydroxycyclobut-3-en-1,2-dione (6)

To a solution of $5(1.19 \mathrm{~g}, 3.10 \mathrm{mmol})$ in EtOH $(50 \mathrm{~mL})$, at reflux, a $40 \%(\mathrm{w} / \mathrm{v}) \mathrm{NaOH}$ aqueous solution $(0.72 \mathrm{~mL}, 7.2 \mathrm{mmol})$ was added and the reaction mixture was kept at boiling for further $25 \mathrm{~min}$. After cooling at room temperature, a $2 \mathrm{M}(3.6 \mathrm{~mL}$, $7.2 \mathrm{mmol}$ ) aqueous $\mathrm{HCl}$ solution was added to the mixture, which was then placed on an ice bath to allow the product to precipitate. The crude product was filtered under reduced pressure, washed with cold distilled water and the obtained crystals were then washed with cold ether. Orange crystals $(0.796 \mathrm{~g}, 79 \%$ yield $)$. Mp $184-186^{\circ} \mathrm{C}$. IR $v_{\max }(\mathrm{KBr}): 2926,1770,1660,1563,1492,1458$, $1415, \quad 1358, \quad 1267, \quad 1154, \quad 1123 . \quad{ }^{1} \mathrm{H} \quad \mathrm{NMR} \quad(600.13 \mathrm{MHz}$, $\left.\mathrm{CDCl}_{3}+\mathrm{DMSO}_{-} \mathrm{d}_{6}\right) \delta: 7.55(1 \mathrm{H}, \mathrm{d}, J=7.2, \mathrm{Ar}-\mathrm{H}), 7.38(1 \mathrm{H}, \mathrm{br} \mathrm{t}$, $J=6.9, \mathrm{Ar}-\mathrm{H}), 7.22(1 \mathrm{H}, \mathrm{br} \mathrm{t}, J=6.9, \mathrm{Ar}-\mathrm{H}), 7.14(1 \mathrm{H}, \mathrm{d}, J=7.8, \mathrm{Ar}-$ $\mathrm{H}), 5.69(1 \mathrm{H}, \mathrm{s}, \mathrm{C}=\mathrm{CH}), 4.04\left(2 \mathrm{H}\right.$, br s, $\left.\mathrm{NCH}_{2}\left(\mathrm{CH}_{2}\right)_{4} \mathrm{CH}_{3}\right), 1.81(2 \mathrm{H}$, br quint, $\left.J=6.0, \mathrm{NCH}_{2} \mathrm{CH}_{2}\left(\mathrm{CH}_{2}\right)_{3} \mathrm{CH}_{3}\right), 1.46(2 \mathrm{H}$, br quint, $J=7.2$, $\left.\mathrm{N}\left(\mathrm{CH}_{2}\right)_{2} \mathrm{CH}_{2}\left(\mathrm{CH}_{2}\right)_{2} \mathrm{CH}_{3}\right), \quad 1.44-1.33\left(4 \mathrm{H}, \mathrm{m}, \mathrm{N}\left(\mathrm{CH}_{2}\right)_{3}\left(\mathrm{CH}_{2}\right)_{2} \mathrm{CH}_{3}\right)$, $0.91\left(3 \mathrm{H}, \mathrm{t}, J=6.9, \mathrm{~N}\left(\mathrm{CH}_{2}\right)_{5} \mathrm{C}_{3}\right)$. ESI-TOFMS $m / z: 330.12[\mathrm{M}+\mathrm{H}]^{+}$.
4.1.5. Synthesis of 2-[(3-hexylbenzothiazol-2(3H)-ylidene)methyl]-4[(1-hexylquinolin-1-ium-2-yl)methylidene]-3-oxocyclobut-1-en-1olate $(\mathbf{9})$

A solution of $\mathbf{6}(1.08 \mathrm{~g}, 3.29 \mathrm{mmol})$ and $8(1.17 \mathrm{~g}, 3.29 \mathrm{mmol})$ in a mixture $(9: 1)$ of $n$-BuOH/pyridine $(43 \mathrm{~mL})$ was heated under reflux for $4 \mathrm{~h}$. After cooling at room temperature, $\mathrm{CH}_{2} \mathrm{Cl}_{2}$ $(100 \mathrm{~mL})$ was added. The organic layer was washed several times with distilled water, before separation by decantation, dried with anhydrous $\mathrm{Na}_{2} \mathrm{SO}_{4}$ and then the solvent was removed under reduced pressure. The resulting solid was recrystallized from $\mathrm{Et}_{2} \mathrm{O} / \mathrm{CH}_{2} \mathrm{Cl}_{2} / \mathrm{MeOH}$. Dark red crystals ( $0.437 \mathrm{~g}, 25 \%$ yield). $\mathrm{Mp}$ 282-284 ${ }^{\circ} \mathrm{C}$ (dec.). Vis $\lambda_{\max }$ (DMSO): $714, \log \varepsilon=5.06$. Vis $\lambda_{\max }$ (DMEM): 627. IR $v_{\max }(\mathrm{KBr}): 2925,1631,1594,1584,1469,1451$, 1425, 1401, 1339, 1289, 1230, 1177, 1165, 1104, 1081, 745. ${ }^{1} \mathrm{H}$ $\operatorname{NMR}\left(600.13 \mathrm{MHz}, \mathrm{CDCl}_{3}+\mathrm{CD}_{3} \mathrm{OD}\right) \delta: 9.17(1 \mathrm{H}, \mathrm{d}, J=9.6, \mathrm{Ar}-\mathrm{H})$, 7.62-7.58 (4H, m, Ar-H), $7.45(1 \mathrm{H}, \mathrm{d}, J=9.0, \operatorname{Ar}-\mathrm{H}), 7.38(1 \mathrm{H}, \mathrm{t}$, $J=8.1, \mathrm{Ar}-\mathrm{H}), 7.32(1 \mathrm{H}, \mathrm{t}, J=7.2, \mathrm{Ar}-\mathrm{H}), 7.21(1 \mathrm{H}, \mathrm{t}, J=7.2, \mathrm{Ar}-\mathrm{H})$, $7.16(1 \mathrm{H}, \mathrm{d}, J=8.4, \mathrm{Ar}-\mathrm{H}), 5.87(1 \mathrm{H}, \mathrm{s}, \mathrm{C}=\mathrm{C} \underline{\mathrm{H}}), 5.83(1 \mathrm{H}, \mathrm{s}, \mathrm{C}=\mathrm{C} \underline{\mathrm{H}})$, $4.25\left(2 \mathrm{H}\right.$, br t, $\left.J=7.8, \mathrm{NCH}_{2}\left(\mathrm{CH}_{2}\right)_{4} \mathrm{CH}_{3}\right), 4.09\left(2 \mathrm{H}\right.$, br t, $J=7.8, \mathrm{NC}_{2}$ $\left.\left(\mathrm{CH}_{2}\right)_{4} \mathrm{CH}_{3}\right), 1.90\left(2 \mathrm{H}\right.$, br s, $\left.\mathrm{NCH}_{2} \mathrm{CH}_{2}\left(\mathrm{CH}_{2}\right)_{3} \mathrm{CH}_{3}\right), 1.85-1.80(2 \mathrm{H}, \mathrm{m}$, $\mathrm{NCH}_{2} \mathrm{CH}_{2}\left(\mathrm{CH}_{2}\right)_{3} \mathrm{CH}_{3}$ ), 1.59 (2H, br quint, $\mathrm{N}\left(\mathrm{CH}_{2}\right)_{2} \mathrm{C}_{2}\left(\mathrm{CH}_{2}\right)_{2} \mathrm{CH}_{3}$ ), 1.47-1.36 (10H, m, N $\left.\left.\left(\mathrm{CH}_{2}\right)_{3}\left(\mathrm{CH}_{2}\right)_{2} \mathrm{CH}_{3}\right)+\mathrm{N}\left(\mathrm{CH}_{2}\right)_{2}\left(\mathrm{CH}_{2}\right)_{3} \mathrm{CH}_{3}\right), 0.95$ (3H, br t, $\left.J=6.6, \mathrm{~N}\left(\mathrm{CH}_{2}\right)_{5} \mathrm{CH}_{3}\right), 0.97-0.91\left(6 \mathrm{H}, \mathrm{m}, \mathrm{N}\left(\mathrm{CH}_{2}\right)_{5} \mathrm{CH}_{3}\right)$. ${ }^{13} \mathrm{C}$ NMR (150.91 MHz, $\left.\mathrm{CDCl}_{3}+\mathrm{CD}_{3} \mathrm{OD}\right) \delta: 173.9,170.2,159.0$, 151.5, 141.4, 139.6, 134.3 (Ar- $\underline{\mathrm{CH}}), 131.9$ (Ar- $\underline{\mathrm{CH}}), 129.2$ (Ar-ㅁH), 128.4, 127.4 (Ar- $\underline{\mathrm{CH}}), 126.3$ (Ar- $\underline{\mathrm{CH}}), 125.5,124.7$ (Ar- $\underline{\mathrm{CH}}), 124.1$

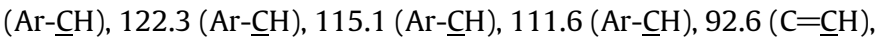
$84.7(\mathrm{C}=\underline{\mathrm{CH}}), 48.7\left(\mathrm{~N}_{\mathrm{CH}}\right)_{2}, 46.4\left(\mathrm{~N}_{\mathrm{CH}}\right)_{2}, 31.7\left(\underline{\mathrm{CH}}_{2}\right), 31.7\left(\underline{\mathrm{CH}}_{2}\right), 27.5$ $\left(\underline{\mathrm{CH}}_{2}\right), 27.1\left(\underline{\mathrm{CH}}_{2}\right), 26.8\left(\underline{\mathrm{CH}}_{2}\right), 26.6\left(\underline{\mathrm{CH}}_{2}\right), 22.9\left(\underline{\mathrm{CH}}_{2}\right), 22.7\left(\underline{\mathrm{CH}}_{2}\right)$, $14.1\left(\mathrm{CH}_{3}\right), 14.1\left(\mathrm{CH}_{3}\right)$. HRESI-TOFMS $\mathrm{m} / z$ calcd for $\mathrm{C}_{34} \mathrm{H}_{38} \mathrm{~N}_{2} \mathrm{O}_{2} \mathrm{~S}$ : 538. 26485 , found: $538.26432[\mathrm{M}]^{+}$.

\subsubsection{Synthesis of 1-hexyl-2-[3-(3-hexylbenzothiazol-2(3H)- ylidenemethyl)-2-methoxy-4-oxocyclobut-2-enylidenemethyl] quinolin-1-ium trifluoromethanesulfonate (10)}

To a solution of squarylium dye $\mathbf{9}(0.634 \mathrm{~g}, 1.18 \mathrm{mmol})$ in anhydrous $\mathrm{CH}_{2} \mathrm{Cl}_{2}(50 \mathrm{~mL})$, stirred under $\mathrm{N}_{2}$ atmosphere at room temperature, an excess of $\mathrm{CF}_{3} \mathrm{SO}_{3} \mathrm{CH}_{3}(0.4 \mathrm{~mL}, 3.54 \mathrm{mmol})$ was added. After $2.5 \mathrm{~h}$, the reaction mixture was quenched with cold $5 \%$ $(\mathrm{w} / \mathrm{v})$ aqueous $\mathrm{NaHCO}_{3}$. The organic layer, after separation by decantation, was dried with anhydrous $\mathrm{Na}_{2} \mathrm{SO}_{4}$ and the solvent was removed under reduced pressure. The crude product was recrystallized from $\mathrm{CH}_{2} \mathrm{Cl}_{2} / \mathrm{MeOH} / \mathrm{Et}_{2} \mathrm{O}$. Bright green crystals (0.744 g, 89\% yield). Mp $189-191^{\circ} \mathrm{C}$. Vis $\lambda_{\max }$ (DMSO): 666, $\log \varepsilon=5.21$. IR $v_{\max }(\mathrm{KBr}): 2930,1642,1506,1446,1430,1414$, $1351,1257,1217,1147,1110,1030 .{ }^{1} \mathrm{H}$ NMR $\left(600.13 \mathrm{MHz}, \mathrm{CDCl}_{3}\right)$ $\delta: 8.76(1 \mathrm{H}, \mathrm{br} \mathrm{s}, \mathrm{Ar}-\mathrm{H}), 7.85(1 \mathrm{H}, \mathrm{d}, J=9.0, \mathrm{Ar}-\mathrm{H}), 7.72(1 \mathrm{H}, \mathrm{t}, J=7.8$, Ar-H), $7.69(1 \mathrm{H}, \mathrm{d}, J=7.8, \mathrm{Ar}-\mathrm{H}), 7.66(1 \mathrm{H}, \mathrm{d}, J=9.0, \mathrm{Ar}-\mathrm{H}), 7.59(1 \mathrm{H}$, $\mathrm{d}, J=7.8, \mathrm{Ar}-\mathrm{H}), 7.44(1 \mathrm{H}, \mathrm{t}, J=7.8, \mathrm{Ar}-\mathrm{H}), 7.42(1 \mathrm{H}, \mathrm{t}, J=7.2, \mathrm{Ar}-\mathrm{H})$, 7.31-7.28 (2H, m, Ar-H), $6.00(1 \mathrm{H}, \mathrm{s}, \mathrm{C}=\mathrm{C} \underline{\mathrm{H}}), 5.65(1 \mathrm{H}, \mathrm{s}, \mathrm{C}=\mathrm{C} \underline{\mathrm{H}})$, $4.61\left(3 \mathrm{H}, \mathrm{s}, \mathrm{OCH}_{3}\right), 4.39\left(2 \mathrm{H}, \mathrm{br} \mathrm{s}, \mathrm{NCH}_{2}\left(\mathrm{CH}_{2}\right)_{4} \mathrm{CH}_{3}\right), 4.32(2 \mathrm{H}, \mathrm{t}$, $\left.J=7.2, \mathrm{NCH}_{2}\left(\mathrm{CH}_{2}\right)_{4} \mathrm{CH}_{3}\right), 1.87$ (2H, quint, $J=7.8, \mathrm{NCH}_{2} \mathrm{CH}_{2}\left(\mathrm{CH}_{2}\right)_{3}-$ $\mathrm{CH}_{3}$ ), 1.80 (2H, quint, $\left.J=7.2, \mathrm{NCH}_{2} \mathrm{CH}_{2}\left(\mathrm{CH}_{2}\right)_{3} \mathrm{CH}_{3}\right), 1.58$ (2H, quint, $\left.J=6.6, \mathrm{~N}\left(\mathrm{CH}_{2}\right)_{2} \mathrm{CH}_{2}\left(\mathrm{CH}_{2}\right)_{2} \mathrm{CH}_{3}\right), 1.44-1.36\left(6 \mathrm{H}, \mathrm{m}, \mathrm{N}\left(\mathrm{CH}_{2}\right)_{2} \mathrm{CH}_{2}\right.$ $\left.\left(\mathrm{CH}_{2}\right)_{2} \mathrm{CH}_{3}+\mathrm{N}\left(\mathrm{CH}_{2}\right)_{3}\left(\mathrm{CH}_{2}\right)_{2} \mathrm{CH}_{3}\right), 1.31\left(4 \mathrm{H}, \mathrm{m}, \mathrm{N}\left(\mathrm{CH}_{2}\right)_{3}\left(\mathrm{CH}_{2}\right)_{2} \mathrm{CH}_{3}\right)$, $0.93\left(3 \mathrm{H}, \mathrm{t}, J=6.9, \mathrm{~N}\left(\mathrm{CH}_{2}\right)_{5} \mathrm{CH}_{3}\right), 0.87\left(3 \mathrm{H}, \mathrm{t}, J=6.9, \mathrm{~N}\left(\mathrm{CH}_{2}\right)_{5} \mathrm{CH}_{3}\right)$. ${ }^{13} \mathrm{C}$ NMR $\left(150.91 \mathrm{MHz}, \mathrm{CDCl}_{3}\right) \delta: 178.1,176.1,161.4,159.3$, 151.9, 140.7, 138.7, 137.2 (Ar- $\underline{\mathrm{CH}}), 133.0(\mathrm{Ar}-\underline{\mathrm{CH}}), 129.5$ (Ar- $\underline{\mathrm{CH}})$, 127.9 (Ar- $\underline{\mathrm{CH}}), 127.7,126.0$ (Ar- $\underline{\mathrm{CH}}), 125.4,125.1$ (Ar- $\underline{\mathrm{CH}}), 124.1$ (Ar- $\underline{\mathrm{CH}}), 122.2(\mathrm{Ar}-\underline{\mathrm{CH}}), 119.7,116.0(\mathrm{Ar}-\underline{\mathrm{CH}}), 112.8(\mathrm{Ar}-\underline{\mathrm{CH}}), 92.1$ 
$(\mathrm{C}=\underline{\mathrm{CH}}), 85.3(\mathrm{C}=\underline{\mathrm{CH}}), 61.1\left(\mathrm{OCH}_{3}\right), 49.2\left(\mathrm{NCH}_{2}\right), 46.8\left(\mathrm{NCH}_{2}\right), 31.4$ $\left(\underline{\mathrm{CH}}_{2}\right), 31.3\left(\underline{\mathrm{CH}}_{2}\right), 27.6(\underline{\mathrm{CH}} \mathrm{2}), 27.3\left(\underline{\mathrm{CH}}_{2}\right), 26.3\left(\underline{\mathrm{CH}}_{2}\right), 26.2\left(\underline{\mathrm{CH}}_{2}\right)$, $22.5\left(\underline{\mathrm{CH}}_{2}\right), 22.4\left(\underline{\mathrm{CH}}_{2}\right), 13.9\left(\underline{\mathrm{CH}}_{3}\right), 13.9\left(\underline{\mathrm{CH}}_{3}\right)$. ESI-TOFMS $\mathrm{m} / \mathrm{z}$ : $553.29\left[\mathrm{M}-\mathrm{CF}_{3} \mathrm{SO}_{3}\right]^{+}$.

4.1.7. Synthesis of 2-[2-amino-3-(3-hexylbenzothiazol-2(3H)ylidenemethyl)-4-oxocyclobut-2-enylidenemethyl]-1-hexylquinolin1-ium iodide (11)

To a solution of $\mathbf{1 0}(0.20 \mathrm{~g}, 0.28 \mathrm{mmol})$ in anhydrous $\mathrm{CH}_{2} \mathrm{Cl}_{2}$ $(20 \mathrm{~mL})$, under $\mathrm{N}_{2}$ atmosphere at room temperature, an excess of a $2 \mathrm{M} \mathrm{NH}_{3}$ solution was added in $\mathrm{MeOH}(0.64 \mathrm{~mL}, 1.28 \mathrm{mmol})$. The reaction mixture was stirred at r.t. for $23 \mathrm{~h}$ and then washed with cold distilled water. The organic layer was separated by decantation and dried with anhydrous $\mathrm{Na}_{2} \mathrm{SO}_{4}$. The solvent was removed under reduced pressure and the resulting product was dissolved again in $\mathrm{MeOH}(10 \mathrm{~mL})$. To this solution equal volume of $14 \%(\mathrm{w} / \mathrm{v})$ aqueous $\mathrm{KI}$ was added. After $2 \mathrm{~h}$, the precipitated dye was collected by filtration under reduced pressure, washed with cold distilled water and recrystallized from $\mathrm{CH}_{2} \mathrm{Cl}_{2} / \mathrm{MeOH} /$ $\mathrm{Et}_{2} \mathrm{O}$. Dark green crystals $(0.133 \mathrm{~g}, 70 \%$ yield $) . \mathrm{Mp} 277-279{ }^{\circ} \mathrm{C}$ (dec). Vis $\lambda_{\max }$ (DMSO): 693, $\log \varepsilon=5.25$. Vis $\lambda_{\max }$ (DMEM): 605 . IV $v_{\max }(\mathrm{KBr}): 3098,2953,1633,1517,1456,1418,1356,1328$, 1272, 1252, 1179, 1156, 1093, 1068, 980. ${ }^{1} \mathrm{H}$ NMR $(600.13 \mathrm{MHz}$, DMSO-d $\left.d_{6}\right) \delta: 8.93(1 \mathrm{H}, \mathrm{d}, J=9.6, \mathrm{Ar}-\mathrm{H}), 8.75(1 \mathrm{H}, \mathrm{br} \mathrm{s}, \underline{\mathrm{H}}$, exchange with $\left.\mathrm{D}_{2} \mathrm{O}\right), 8.62\left(1 \mathrm{H}\right.$, br $\mathrm{s}, \mathrm{N} \underline{\mathrm{H}}$, exchange with $\left.\mathrm{D}_{2} \mathrm{O}\right), 7.96(1 \mathrm{H}, \mathrm{d}$, $J=9.6, \mathrm{Ar}-\mathrm{H}), 7.85(1 \mathrm{H}, \mathrm{d}, J=7.8, \mathrm{Ar}-\mathrm{H}), 7.77(2 \mathrm{H}, \mathrm{br} \mathrm{t}, J=6.3, \mathrm{Ar}-$ $\mathrm{H}), 7.71(1 \mathrm{H}, \mathrm{t}, J=7.5, \mathrm{Ar}-\mathrm{H}), 7.55(1 \mathrm{H}, \mathrm{d}, J=7.8, \mathrm{Ar}-\mathrm{H}), 7.45-7.40$ $(2 \mathrm{H}, \mathrm{m}, \mathrm{Ar}-\mathrm{H}), 7.26(1 \mathrm{H}, \mathrm{t}, J=7.5, \mathrm{Ar}-\mathrm{H}), 6.01(1 \mathrm{H}, \mathrm{s}, \mathrm{C}=\mathrm{C} \underline{\mathrm{H}}), 5.87$ $(1 \mathrm{H}, \mathrm{s}, \mathrm{C}=\mathrm{C} \underline{\mathrm{H}}), 4.31\left(2 \mathrm{H}\right.$, br s, $\left.\mathrm{NC}_{2}\left(\mathrm{CH}_{2}\right)_{4} \mathrm{CH}_{3}\right), 4.15(2 \mathrm{H}$, br $\mathrm{t}$, $\left.J=7.2, \mathrm{NCH}_{2}\left(\mathrm{CH}_{2}\right)_{4} \mathrm{CH}_{3}\right), 1.72-1.66\left(4 \mathrm{H}, \mathrm{m}, \mathrm{NCH}_{2} \mathrm{CH}_{2}\left(\mathrm{CH}_{2}\right)_{3} \mathrm{CH}_{3}+\right.$ $\left.\mathrm{NCH}_{2} \mathrm{CH}_{2}\left(\mathrm{CH}_{2}\right)_{3} \mathrm{CH}_{3}\right), 1.51$ (2H, br quint, $\mathrm{N}\left(\mathrm{CH}_{2}\right)_{2} \mathrm{CH}_{2}\left(\mathrm{CH}_{2}\right)_{2} \mathrm{CH}_{3}$ ), $1.40\left(2 \mathrm{H}\right.$, br quint, $\left.\mathrm{N}\left(\mathrm{CH}_{2}\right)_{2} \mathrm{CH}_{2}\left(\mathrm{CH}_{2}\right)_{2} \mathrm{CH}_{3}\right), 1.33-1.26(8 \mathrm{H}, \mathrm{m}, \mathrm{N}$ $\left.\left(\mathrm{CH}_{2}\right)_{3}\left(\mathrm{CH}_{2}\right)_{2} \mathrm{CH}_{3}\right), 0.88\left(3 \mathrm{H}, \mathrm{t}, J=6.9, \mathrm{~N}\left(\mathrm{CH}_{2}\right)_{5} \mathrm{CH}_{3}\right), 0.85(3 \mathrm{H}, \mathrm{t}$, $\left.J=6.9, \mathrm{~N}\left(\mathrm{CH}_{2}\right)_{5} \mathrm{C}_{3}\right) .{ }^{13} \mathrm{C}$ NMR $\left(150.9 \mathrm{MHz}\right.$, DMSO-d $\left.d_{6}\right) \delta: 174.5$, $167.3,159.6,158.6,154.9,151.3,140.9,138.8,136.0(\mathrm{Ar}-\mathrm{CH})$, 132.7 (Ar- $\underline{\mathrm{CH}}), 129.3$ (Ar- $\underline{\mathrm{CH}}), 127.7(\mathrm{Ar}-\underline{\mathrm{CH}}), 127.4,125.4$ (Ar$\mathrm{CH}), 125.1,124.5(\mathrm{Ar}-\underline{\mathrm{CH}}), 124.5(\mathrm{Ar}-\underline{\mathrm{CH}}), 122.8(\mathrm{Ar}-\underline{\mathrm{CH}}), 116.4$ $(\mathrm{Ar}-\underline{\mathrm{CH}}), 113.0(\mathrm{Ar}-\mathrm{CH}), 93.9(\mathrm{C}=\underline{\mathrm{CH}}), 85.6(\mathrm{C}=\mathrm{CH}), 48.2\left(\mathrm{NCH}_{2}\right)$, $46.1\left(\mathrm{NCH}_{2}\right), 31.3\left(\mathrm{CH}_{2}\right), 31.2\left(\mathrm{CH}_{2}\right), 27.2\left(\mathrm{CH}_{2}\right), 27.1\left(\mathrm{CH}_{2}\right), 26.0$ $\left(\underline{\mathrm{CH}}_{2}\right), 25.8\left(\underline{\mathrm{CH}}_{2}\right), 22.4\left(\underline{\mathrm{CH}}_{2}\right), 22.3\left(\underline{\mathrm{CH}}_{2}\right), 14.1\left(\underline{\mathrm{CH}}_{3}\right), 14.1\left(\underline{\mathrm{CH}}_{3}\right)$. HRESI-TOFMS $\mathrm{m} / \mathrm{z}$ calcd for $\mathrm{C}_{34} \mathrm{H}_{40} \mathrm{~N}_{3} \mathrm{OS}$ : 538.28866, found: $538.28785[\mathrm{M}-\mathrm{I}]^{+}$.

4.1.8. Synthesis of 1-hexyl-2-[3-(3-hexylbenzothiazol-2(3H)ylidenemethyl)-2-methylamino-4-oxocyclobut-2-enylidenemethyl]quinolin-1-ium iodide (12)

To a solution of $\mathbf{1 0}(0.20 \mathrm{~g}, 0.28 \mathrm{mmol})$ in anhydrous $\mathrm{CH}_{2} \mathrm{Cl}_{2}$ $(20 \mathrm{~mL})$, under $\mathrm{N}_{2}$ atmosphere at r.t., an excess of $2 \mathrm{M} \mathrm{NH}_{2} \mathrm{CH}_{3}$ solution in tetrahydrofuran $(0.64 \mathrm{~mL}, 1.28 \mathrm{mmol})$, was added. The reaction mixture was stirred at room temperature for $30 \mathrm{~min}$. and then washed with cold distilled water. The organic layer was separated by decantation and dried with anhydrous $\mathrm{Na}_{2} \mathrm{SO}_{4}$. The solvent was removed under reduced pressure and the resulting product was dissolved in $\mathrm{MeOH}(10 \mathrm{~mL})$. To this solution an equal volume of $14 \%(\mathrm{w} / \mathrm{v})$ aqueous KI was added. After $2 \mathrm{~h}$, the precipitated dye was collected by filtration under reduced pressure, washed with cold distilled water and recrystallized from $\mathrm{CH}_{2} \mathrm{Cl}_{2}$ / $\mathrm{Et}_{2} \mathrm{O}$. Dark-purple crystals $(0.130 \mathrm{~g}, 67 \%$ yield $)$. Mp $212-214{ }^{\circ} \mathrm{C}$. Vis $\lambda_{\text {max }}$ (DMSO): $704, \log \varepsilon=5.17$. Vis $\lambda_{\text {max }}$ (DMEM): 631. IV $v_{\max }$ (KBr): 2924, 1626, 1563, 1457, 1433, 1348, 1258, 1158, 1109. ${ }^{1} \mathrm{H}$
NMR (600.13 MHz, DMSO- $\left.d_{6}\right) \delta: 8.96(1 \mathrm{H}, \mathrm{d}, J=9.6, \mathrm{Ar}-\mathrm{H}), 8.88$ $(1 \mathrm{H}, \mathrm{d}, J=9.0, \operatorname{Ar}-\mathrm{H}), 8.80\left(1 \mathrm{H}\right.$, br $\mathrm{d}, \mathrm{N} \underline{\mathrm{H}}$, exchange with $\left.\mathrm{D}_{2} \mathrm{O}\right)$, $8.70\left(1 \mathrm{H}\right.$, br d, $\mathrm{NH}$, exchange with $\left.\mathrm{D}_{2} \mathrm{O}\right), 8.02(1 \mathrm{H}, \mathrm{d}, J=9.0, \mathrm{Ar}-$ $\mathrm{H}), 7.87(2 \mathrm{H}, \mathrm{t}, J=9.3, \mathrm{Ar}-\mathrm{H}), 7.83-7.80(3 \mathrm{H}, \mathrm{m}, \mathrm{Ar}-\mathrm{H}), 7.77(1 \mathrm{H}$ $\mathrm{d}, J=8.4, \mathrm{Ar}-\mathrm{H}), 7.72(2 \mathrm{H}$, br s, Ar-H), 7.68-7.64 $(1 \mathrm{H}, \mathrm{m}, \mathrm{Ar}-\mathrm{H})$ $7.56(1 \mathrm{H}, \mathrm{d}, J=7.8, \mathrm{Ar}-\mathrm{H}), 7.53(1 \mathrm{H}, \mathrm{d}, J=7.8, \mathrm{Ar}-\mathrm{H}), 7.44(2 \mathrm{H}, \mathrm{t}$, $J=7.5, \operatorname{Ar}-\mathrm{H}), 7.41(1 \mathrm{H}, \mathrm{d}, J=7.8, \mathrm{Ar}-\mathrm{H}), 7.37(1 \mathrm{H}, \mathrm{t}, J=7.2, \mathrm{Ar}-\mathrm{H})$, $7.28(1 \mathrm{H}, \mathrm{t}, J=7.2, \mathrm{Ar}-\mathrm{H}), 7.24(1 \mathrm{H}, \mathrm{t}, J=7.2, \mathrm{Ar}-\mathrm{H}), 5.99(1 \mathrm{H}, \mathrm{s}$, $\mathrm{C}=\mathrm{CH}), 5.87(1 \mathrm{H}, \mathrm{s}, \mathrm{C}=\mathrm{CH}), 5.84(1 \mathrm{H}, \mathrm{s}, \mathrm{C}=\mathrm{C} \underline{\mathrm{H}}), 5.74(1 \mathrm{H}, \mathrm{s}, \mathrm{C}=\mathrm{C} \underline{\mathrm{H}})$ $4.28\left(4 \mathrm{H}, \mathrm{m}, \mathrm{NCH}_{2}\left(\mathrm{CH}_{2}\right)_{4} \mathrm{CH}_{3}\right), 4.22\left(2 \mathrm{H}\right.$, br s, $\left.\mathrm{NC}_{2}\left(\mathrm{CH}_{2}\right)_{4} \mathrm{CH}_{3}\right), 4.13$ $\left(2 \mathrm{H}\right.$, br $\left.s, \mathrm{NCH}_{2}\left(\mathrm{CH}_{2}\right)_{4} \mathrm{CH}_{3}\right), 3.29\left(3 \mathrm{H}, \mathrm{d}, J=4.2, \mathrm{NHCH}_{3}\right), 3.26(3 \mathrm{H}, \mathrm{d}$ $\left.J=3.6, \mathrm{NHCH}_{3}\right), 1.67\left(8 \mathrm{H}\right.$, br s, $\left.\mathrm{NCH}_{2} \mathrm{CH}_{2}\left(\mathrm{CH}_{2}\right)_{3} \mathrm{CH}_{3}\right), 1.51(2 \mathrm{H}, \mathrm{br} \mathrm{s}$, $\left.\mathrm{N}\left(\mathrm{CH}_{2}\right)_{2} \mathrm{CH}_{2}\left(\mathrm{CH}_{2}\right)_{2} \mathrm{CH}_{3}\right), 1.44\left(2 \mathrm{H}\right.$, br s, $\left.\mathrm{N}\left(\mathrm{CH}_{2}\right)_{2} \mathrm{CH}_{2}\left(\mathrm{CH}_{2}\right)_{2} \mathrm{CH}_{3}\right), 1.36$ (4H, br s, $\left.\mathrm{N}\left(\mathrm{CH}_{2}\right)_{2} \mathrm{C}_{2}\left(\mathrm{CH}_{2}\right)_{2} \mathrm{CH}_{3}\right), 1.31-1.27\left(16 \mathrm{H}, \mathrm{m}, \mathrm{N}\left(\mathrm{CH}_{2}\right)_{3}\right.$ $\left.\left(\mathrm{C}_{2}\right)_{2} \mathrm{CH}_{3}\right), \quad 0.87-0.83 \quad\left(12 \mathrm{H}, \quad \mathrm{m}, \quad \mathrm{N}\left(\mathrm{CH}_{2}\right)_{5} \underline{\mathrm{C}}_{3}\right) . \quad{ }^{1} \mathrm{H} \quad \mathrm{NMR}$ $\left(400.13 \mathrm{MHz}\right.$, DMSO- $\left.d_{6}, 363.15 \mathrm{~K}\right) \delta: 8.95(1 \mathrm{H}, \mathrm{d}, J=9.2, \mathrm{Ar}-\mathrm{H})$, $8.02(1 \mathrm{H}, \mathrm{d}, J=9.6, \mathrm{Ar}-\mathrm{H}), 7.88-7.84(3 \mathrm{H}, \mathrm{m}, \operatorname{Ar}-\mathrm{H}), 7.78(1 \mathrm{H}, \mathrm{t}$, $J=8.4, \mathrm{Ar}-\mathrm{H}), 7.56(1 \mathrm{H}, \mathrm{d}, J=8.4, \mathrm{Ar}-\mathrm{H}), 7.52-7.47(2 \mathrm{H}, \mathrm{m}, \mathrm{Ar}-\mathrm{H})$, $7.31(1 \mathrm{H}, \mathrm{t}, J=7.6, \mathrm{Ar}-\mathrm{H}), 6.03(1 \mathrm{H}, \mathrm{s}, \mathrm{C}=\mathrm{CH}), 5.97(1 \mathrm{H}, \mathrm{s}, \mathrm{C}=\mathrm{CH})$, $4.47\left(2 \mathrm{H}, \mathrm{t}, J=6.4, \mathrm{NC}_{2}\left(\mathrm{CH}_{2}\right)_{4} \mathrm{CH}_{3}\right), 4.27\left(2 \mathrm{H}, \mathrm{t}, J=7.4, \mathrm{NCH}_{2}\left(\mathrm{CH}_{2}\right)_{4}\right.$ $\left.\mathrm{CH}_{3}\right), 3.36\left(3 \mathrm{H}, \mathrm{s}, \mathrm{NHCH}_{3}\right), 1.83\left(2 \mathrm{H}\right.$, quint, $J=7.7, \mathrm{NCH}_{2} \mathrm{CH}_{2}\left(\mathrm{CH}_{2}\right)_{3}$ $\left.\mathrm{CH}_{3}\right), 1.78$ (2H, quint, $\left.J=7.6, \mathrm{NCH}_{2} \mathrm{CH}_{2}\left(\mathrm{CH}_{2}\right)_{3} \mathrm{CH}_{3}\right), 1.53$ (2H, quint, $\left.J=7.4, \mathrm{~N}\left(\mathrm{CH}_{2}\right)_{2} \mathrm{CH}_{2}\left(\mathrm{CH}_{2}\right)_{2} \mathrm{CH}_{3}\right), 1.41-1.29\left(10 \mathrm{H}, \mathrm{m}, \mathrm{N}\left(\mathrm{CH}_{2}\right)_{2}\left(\mathrm{CH}_{2}\right)_{3}-\right.$ $\left.\mathrm{CH}_{3}+\mathrm{N}\left(\mathrm{CH}_{2}\right)_{3}\left(\mathrm{CH}_{2}\right)_{2} \mathrm{CH}_{3}\right), 0.91-0.85\left(6 \mathrm{H}, \mathrm{m}, \mathrm{N}\left(\mathrm{CH}_{2}\right)_{5} \mathrm{CH}_{3}\right) .{ }^{13} \mathrm{C} \mathrm{NMR}$ $\left(150.9 \mathrm{MHz}, \mathrm{DMSO}^{-} d_{6}, 298.15 \mathrm{~K}\right) \delta: 174.0,173.8,165.6,165.4$ $160.3,158.5,158.0,157.5,154.9,153.6,151.5,150.6,140.9$, 140.8, 139.0, 138.7, 136.6 (Ar-다), 135.3 (Ar-다), 132.9 (Ar- $\underline{\mathrm{CH}})$, 132.5 ( $\mathrm{Ar}-\underline{\mathrm{CH}}), 129.4$ ( $\mathrm{Ar}-\underline{\mathrm{CH}}), 129.1$ (Ar- $\underline{\mathrm{CH}}), 127.8$ ( $\mathrm{Ar}-\underline{\mathrm{CH}}), 127.7$ (Ar-다), 127.6, 125.7 ( $\mathrm{Ar}-\underline{\mathrm{CH}}), 125.3,125.1$ (Ar- $\underline{\mathrm{CH}}), 124.8$ (Ar-

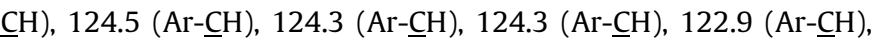
122.6 (Ar- $\underline{\mathrm{CH}}), 116.6$ (Ar-대), $116.2(\mathrm{Ar}-\underline{\mathrm{CH}}), 113.2(\mathrm{Ar}-\underline{\mathrm{CH}}), 112.8$ (Ar- $\underline{\mathrm{CH}}), 94.3(\mathrm{C}=\underline{\mathrm{CH}}), 93.9(\mathrm{C}=\underline{\mathrm{C}} \mathrm{H}), 85.9(\mathrm{C}=\underline{\mathrm{CH}}), 85.8(\mathrm{C}=\underline{\mathrm{CH}})$, $48.5\left(\mathrm{NCH}_{2}\right), 48.4\left(\mathrm{NCH}_{2}\right), 46.3\left(\mathrm{NCH}_{2}\right), 45.6\left(\mathrm{NCH}_{2}\right), 31.2\left(\underline{\mathrm{CH}}_{2}\right)$, $\left.31.1\left(\underline{\mathrm{CH}}_{2}\right), 31.1\left(\underline{\mathrm{CH}}_{2}\right), 31.0\left(\underline{\mathrm{CH}}_{2}\right), 30.4\left(\mathrm{NHCH}_{3}\right), 30.2\left(\mathrm{NH}^{\mathrm{CH}}\right)_{3}\right)$, $27.3\left(\mathrm{CH}_{2}\right), 27.2\left(\mathrm{CH}_{2}\right), 26.9\left(\underline{\mathrm{CH}}_{2}\right), 26.7\left(\underline{\mathrm{CH}}_{2}\right), 25.9\left(\mathrm{CH}_{2}\right), 25.9$ $\left(\underline{\mathrm{CH}}_{2}\right), 25.8\left(\underline{\mathrm{CH}}_{2}\right), 22.4\left(\underline{\mathrm{CH}}_{2}\right), 22.3\left(\underline{\mathrm{CH}}_{2}\right), 22.2\left(\underline{\mathrm{CH}}_{2}\right), 22.2\left(\underline{\mathrm{CH}}_{2}\right)$, $14.1\left(\underline{\mathrm{CH}}_{3}\right), 14.0\left(\underline{\mathrm{CH}}_{3}\right), 14.0\left(\underline{\mathrm{CH}}_{3}\right)$. HRESI-TOFMS $\mathrm{m} / \mathrm{z}$ calcd for $\mathrm{C}_{35} \mathrm{H}_{42} \mathrm{~N}_{3} \mathrm{OS}$ : 552.30431, found: $552.30339[\mathrm{M}-\mathrm{I}]^{+}$.

\subsection{Singlet oxygen formation quantum yields}

The quantum yield of singlet oxygen formation was measured as previously described. ${ }^{6}$ Briefly, a system equipped with a nitrogen laser was used $(337 \mathrm{~nm})$, the detection system was an InGaAs CCD (Andor, i-Dus model) working at low temperature $\left(-60^{\circ} \mathrm{C}\right)$ which was coupled to a fixed spectrograph (Andor, model Shamrock 163i). Long pass filters were used to exclude the excitation radiation from reaching the detector (LFP1100, CVI Lasers). The quantum yields of singlet oxygen formation $(\varphi \Delta)$ were measured in chloroform, with optical density of 0.6 at $337 \mathrm{~nm}$, using phenazine as standard $(\varphi \Delta=0.84)$.

\subsection{Dyes cytotoxicity evaluation: In vitro study}

\subsubsection{General methods}

DMEM (Dulbecco's Modified Eagle Medium), fetal bovine serum (FBS), penicillin/streptomycin, L-glutamine, $0.05 \%$ trypsin-EDTA and Alamar Blue $(A B)$ were purchased from Gibco (Alfagene, Invitrogen, Portugal). Ultra-purified water was obtained from MiliQ ${ }^{\circledR}$ Plus system (Milipore, Germany). HepG2 (Human hepatocellular carcinoma cell line; ATCC ${ }^{\circledR}$ Number: HB-8065TM) was a gift from 
Professor Carlos Palmeira (CNC-UC, Coimbra, Portugal) and Caco-2 (Human colon adenocarcinoma cell line) was purchased from Cell Lines Service (CLS, Eppelheim, Germany).

\subsubsection{Cell culture}

HepG2 and Caco-2 cell lines were grown in DMEM supplemented with $10 \%(\mathrm{v} / \mathrm{v})$ FBS, $1 \mathrm{mM}$ L-glutamine, $100 \mathrm{U} / \mathrm{mL}$ penicillin and $100 \mu \mathrm{g} / \mathrm{mL}$ streptomycin (all cell culture reagents from Gibco, Alfagene, Portugal). Cells were maintained at $37{ }^{\circ} \mathrm{C}$ and $5 \% \mathrm{CO}_{2} / 95 \%$ air environment, and handled as previously described. ${ }^{41,42}$

\subsubsection{Cell exposure to dyes and irradiation assay}

Solutions in the millimolar $\left(\sim 10^{-4} \mathrm{M}\right)$ range of dye 9 (DMSO: $\mathrm{CH}_{2} \mathrm{Cl}_{2} ; 24: 1$ ), 11 and 12 (DMSO) were prepared. HepG2 and Caco-2 cells were seeded in 96-well microplates at a cell density of $5 \times 10^{4}$ cells $/ \mathrm{mL}(100 \mu \mathrm{L} /$ well $)$ and incubated at $37^{\circ} \mathrm{C}$ under $5 \%$ $\mathrm{CO}_{2}$ in fresh cell culture medium. After $24 \mathrm{~h}$ of seeding, the medium was replaced by FBS-free medium with different concentrations of the dyes 9, 11 and 12. Four concentrations of each compound were tested $(0.1,1.0,5.0$ and $10.0 \mu \mathrm{M})$. The effects of the solvents were also assessed by incubating the cells with the same volume as that in the highest concentration for the same periods of time and subjecting them to the same procedures. Cells were exposed to the dyes for $24 \mathrm{~h}$ (in the incubator) before the irradiation procedure.

The irradiation system was performed with a self-designed and constructed apparatus, consisting in an arrangement of LEDs of desired wavelength, placed at each well of a 96-well plate, in order to have a system that the reproducible alignments of the irradiation light with the seeded cells. The apparatus was built using aluminium gallium Indium phosphide (AlGaInP) LEDs (Roithner B5B-445-TL) with a spectral emission peak at $\lambda=630 \mathrm{~nm}$ $(630.8 \pm 0.8)$, with $P=4.3 \pm 0.5 \mathrm{~mW}$ operating at $20 \mathrm{~mA}$. The apparatus was placed over the 96-well plates, with the LEDs facing the cells, and each LED illuminated a single well at a distance of approximately $1.5 \mathrm{~cm}$. Cells were irradiated using three different conditions: i) $0 \mathrm{~min}$ of irradiation (without irradiation), 14 min outside the incubator; ii) 7 min of irradiation (total energy applied $=1.81 \mathrm{~J}$ ); iii) $14 \mathrm{~min}$ of irradiation (total energy applied $=3.61 \mathrm{~J}$ ). The irradiation was performed at room temperature, protected from ambient light, with temperature control to avoid overheat of apparatus (i.e. over $37^{\circ} \mathrm{C}$ ). After irradiation, cells were incubated for another $1 \mathrm{~h}$ or $24 \mathrm{~h}$ with irradiated dyes. After this period, the media containing the dye solutions was removed and the cells were gently washed twice with PBS (in mM: 137.0 $\mathrm{NaCl}, 2.7 \mathrm{KCl}, 1.75 \mathrm{KH}_{2} \mathrm{PO}_{4}, 10.0 \mathrm{Na}_{2} \mathrm{HPO}_{4}, \mathrm{pH}$ adjusted to 7.4 ) (100 $\mu \mathrm{L} /$ well/wash) and cell viability was assessed.

Cell viability was assessed using $A B$ assay, by adding $A B$ solution at $10 \%(\mathrm{v} / \mathrm{v})$ in FBS-free culture media $(100 \mu \mathrm{L} /$ well $)$. The absorbance, at $570 \mathrm{~nm}$ (reduced form) and at $620 \mathrm{~nm}$ (oxidized form), was read about $4-5 \mathrm{~h}$ after exposure $A B$. Data were analyzed by calculating the percentage of $\mathrm{AB}$ reduction and expressed as percentage of control (non-exposed cells, $0 \mu \mathrm{M}$ ), as previously described, ${ }^{41}$ in each condition.

\subsubsection{Statistical analysis}

Results are presented as the mean value \pm standard deviation (mean \pm SD), of at least three independent experiments. Statistical significance of differences between groups was assessed by oneway ANOVA test. Results were considered significantly different if $p<0.05$. Graphs were constructed using GraphPad Prism software (GraphPad Software Inc., US) and statistical analysis was performed using Origin Pro 8 software tools. In the statistical analysis indicated in the graphics we compared: i) different dye concentrations versus control (non-exposed), at same irradiation period and exposure condition (marked with an ${ }^{*}$ ); and ii) different exposure times to irradiated dye (marked with an ${ }^{*}$ ); other comparisons are mentioned in the text together with the $p$ values.

\section{Conflicts of interest}

None to declare.

\section{Acknowledgements}

We acknowledge the European Investment Funds by FEDER/ COMPETE/POCI under projects POCI-01-0145-FEDER-006958 (CITAB) and POCI-01-0145-FEDER-007491 (CICS-UBI) and Funds by FCT - Portuguese Foundation for Science and Technology, under the projects UID/AGR/04033/2013 (CITAB) and Pest-OE/QUI/ UI0616/2014 (CQ-VR). FCT is also acknowledged for the PhD fellowship SFRH/BD/95359/2013 to DF. Financial support was also received from FCT and from European Funds (PRODER/COMPETE) under the projects M-ERA-NET-0004/2015-PAIRED and project UID/Multi/00709/2013 (CICS-UBI) and co-financed by FEDER, under the Partnership Agreement PT2020.

\section{A. Supplementary data}

Supplementary data associated with this article can be found, in the online version, at http://dx.doi.org/10.1016/j.bmc.2017.05.022.

\section{References}

1. Tatikolov AS, Panova IG, Ishchenko AA, Kudinova MA. Biophysics (Oxf). 2010;55:35-40.

2. Kim SH, Hwang SH. Dye. Pigment. 1998;36:139-148.

3. Santos PF, Reis LV, Almeida P, Oliveira AS, Ferreira LFV. J. Photochem. Photobiol. A Chem. 2003;160:159-161.

4. Santos PF, Reis LV, Almeida P, Serrano JP, Oliveira AS, Vieira Ferreira L. F. J. Photochem. Photobiol. A Chem. 2004;163:267-269.

5. Avirah RR, Jayaram DT, Adarsh N, Ramaiah D. Org Biomol Chem. 2012;10:911-920.

6. Ferreira DP, Conceição DS, Ferreira VRA, Graça VC, Santos PF, Vieira Ferreira L. F, Photochem Photobiol Sci. 2013;12:1948-1959.

7. Panigrahi M, Dash S, Patel S, Mishra BK. Tetrahedron. 2012;68:781-805.

8. Gromov SP, Fomina MV, Nikiforov AS, Vedernikov AI. Kuz'mina, L. G.; Howard, J. A. K. Tetrahedron. 2013;69:5898-5907.

9. Tatikolov ASJ. Photochem. Photobiol. C Photochem. Rev. 2012;13:55-90.

10. Castano AP, Mroz P, Hamblin MR. Nat Rev Cancer. 2006;6:535-545.

11. Robertson CA, Evans DH, Abrahamse HJ. Photochem. Photobiol. B Biol. 2009;96:1-8.

12. Master A, Livingston M, Sen A. J Control Release. 2013;168:88-102.

13. Severino P, De Hollanda LM, Santini A, Reis LV, Souto SB, Souto EB, Silva AMNanobiomaterials in Cancer Therapy. Elsevier; 2016:91-115.

14. Buytaert E, Dewaele M, Agostinis P. Biochim Biophys Acta. 2007;1776:86-107.

15. Agostinis P, Berg K, Cengel KA, et al. CA. Cancer J. Clin. 2011;61:250-281.

16. Yoo J, Ha K. In: Jeon KW, ed. International Review Of Cell and Molecular Biology, Vol. 295. Elsevier Inc.; 2012:139-174.

17. Allison RR, Sibata CH. Photodiagnosis Photodyn Ther. 2010;7:61-75.

18. Plaetzer K, Krammer B, Berlanda J, Berr F, Kiesslich T. Lasers Med Sci. 2009;24:259-268.

19. Babilas P, Schreml S, Landthaler M, Szeimies R-M. Photodermatol Photoimmunol Photomed. 2010;26:118-132.

20. Brancaleon L, Moseley H. Lasers Med Sci. 2002;17:173-186.

21. Enk CD, Levi A. Photodermatol Photoimmunol Photomed. 2012;28:332-334.

22. Ormond AB, Freeman HS. Materials (Basel). 2013;6:817-840.

23. Abrahamse H, Hamblin MR. Biochem. J. 2016;473:347-364.

24. Reis LV, Serrano JP, Almeida P, Santos PF. Dye. Pigment. 2009;81:197-202.

25. Graça VC, Silva MS, Reis LV, et al. Chromatographia. 2014;77:1529-1537.

26. Kim S, Mor GK, Paulose M, Varghese OK, Baik C, Grimes CA. Langmuir. 2010;26:13486-13492.

27. Luo C, Zhou Q Jiang G, He L, Zhang B, Wang X. New J Chem. 2011;35:1128-1132.

28. Reis LV, Serrano JP, Almeida P, Santos PF. Synlett. 2002;10:1617-1620.

29. Alex S, Basheer MC, Arun KT, Ramaiah D, Das S. J Phys Chem A. 2007:111:3226-3230.

30. Kim SH, Hwang SH. Dye. Pigment. 1997;35:111-121.

31. Kim SH, Hwang SH, Kim JJ, Yoon CM, Keum SR. Dye. Pigment. 1998;37:145-154.

32. Silva MS, Graça VC, Reis LV, et al. Biomed Chromatogr. 2013;27:1671-1679.

33. Santos PF, Reis LV, Almeida P, Lynch DE. CrystEngComm. 2011;13:1333-1338.

34. Ocakoglu K, Er O, Kiyak G, Lambrecht FY, Gunduz C, Kayabasi C. Int J Pharm. 2015;493:96-101. 
35. Delaey E, van Laar F, De Vos D, Kamuhabwa A, Jacobs P, de Witte PJ. Photochem. Photobiol. B Biol. 2000;55:27-36.

36. Fadda AA, El-Mekawy RE. Dye. Pigment. 2013;99:512-519.

37. Serpe L, Ellena S, Barbero N, et al. Eur J Med Chem. 2016;113:187-197.

38. Soumya MS, Shafeekh KM, Das S, Abraham A. Chem Biol Interact. 2014;222:44-49.
39. Amarego WLF, Perrin DD. Purification of Laboratory Chemicals. 4th ed. Oxford: 1996.

40. Pardal AC, Ramos SS, Santos PF, Reis LV, Almeida P. Molecules. 2002;7:320-330.

41. Andreani T, Kiill CP, Souza ALR, et al. Colloids Surf B. 2014;123:916-923.

42. Severino P, Andreani T, Jäger A, et al. Eur J Med Chem. 2014;81:28-34. 